\title{
A GENEALOGIA DA NOÇÃO DE DIREITO INTERNACIONAL
}

\author{
Paulo Emílio Vauthier Borges de Macedo*
}

\begin{abstract}
RESUMO
O presente artigo mostra a origem da noção de "direito internacional". Trata-se de um ensaio de história das idéias que se inicia com os grandes autores romanos e perpassa os principais escritores medievais até Francisco de Vitória. Os demais escolásticos espanhóis e Hugo Grócio são intencionalmente postos de lado pois demandam estudos mais detalhados. $\mathrm{O}$ direito internacional surge somente quando se torna autônomo do direito natural (ainda que embasado nele) e versa sobre institutos verdadeiramente internacionais (não institutos de direito interno que existem em diversos países).
\end{abstract}

PALAVRAS-CHAVE: direito das gentes; direito natural; Francisco de Vitória.

\begin{abstract}
This paper presents the origin of the concept of "international law". It is an essay on History of Ideas which begins with the great Roman authors and pervades the major Medieval writers until Francisco de Vitoria. Other Scholastics Spaniards and Hugo Grotius are intentionally sidelined since they demand more detailed studies. International law arises only when it becomes autonomous from natural law (albeit based on it) and encompasses truly international institutes (and not institutes of domestic law that exist in several countries).
\end{abstract}

KEYWORDS: law of the peoples; natural law; Francisco de Vitoria.

\section{Introdução}

A disciplina de direito internacional foi batizada, em 1780, pelo filósofo Jeremias Bentham, em seu livro An Introduction to the Principles of Moral and Legislation. Na tradução para o francês feita pelo suíço Étienne Dumont, em 1802, a expressão international law tornou-se droit international, e a nova denominação encontrou acolhida imediata entre a maioria dos doutrinadores e os programas oficiais de ensino. Dumont também inseriu o adjetivo "público" ao final. ${ }^{1}$

A tradução, de fato, revela-se imperfeita. Nation, em francês, provém de naissance, nascimento; enquanto, em inglês, conserva-se a polissemia de nação, país ou Estado. A ênfase de Bentham, no entanto, incidia sobre o prefixo "inter". O pensador desejava enfatizar a idéia de que este ramo do Direito aplicava-se entre os povos; noção que, segundo Bentham, o primeiro nome da disciplina, "direito das gentes", mantinha ambígua.

\footnotetext{
* Professor de Direito Internacional, doutor pela Universidade do Estado do Rio de Janeiro, bacharel e mestre em Direito pela Universidade Federal de Santa Catarina, autor dos livros O nascimento do direito internacional, Guerra e Cooperação Internacional e Hugo Grócio e o Direito: o jurista da guerra e da paz, e-mail: borgesmacedo@ hotmail.com.

${ }^{1}$ Cf. TRUYOL, Antonio. Noções Fundamentais de Direito Internacional Público. Trad. Ehrhardt Soares. Coimbra: Armênio Amado, 1952. p. 19.
} 
O que Bentham julgava ambigüidade constituía outra concepção bastante diferente. De fato, o conceito de direito das gentes não equivale, de modo necessário, ao de direito internacional. Se este último for compreendido como um direito positivo entre Estados soberanos todos iguais juridicamente entre si, então, quiçá, o primeiro jusinternacionalista teria sido Emerich de Vattel. De fato, não há correspondência alguma entre os títulos de um sumário de um manual de direito internacional e os das obras de Hugo Grócio ou daquelas dos escolásticos espanhóis. Estes autores escreveram sobre um tema que guarda semelhanças com o direito internacional, mas que não coincide perfeitamente com ele. Trata-se do direito de guerra medieval, a doutrina da guerra justa.

No final do século XIX e início do século XX, começa a surgir uma literatura que considera o jurista de Delft e seus precursores escolásticos como legítimos expoentes da tradição da guerra justa. Isso ocorre porque se passa a compreender esta doutrina como a origem do direito internacional. "A Idade Média viu surgir algumas instituições de direito das gentes, mas elas eram mirradas demais para que se pudesse levá-las em consideração. Apenas o direito da guerra se desenvolveria seriamente; ele forma o núcleo do direito internacional."2 Antes mesmo do aparecimento de estudos autônomos sobre o direito das gentes, já havia trabalhos sobre alguns dos seus institutos - o direito das embaixadas, do comércio, a escravidão. O direito da guerra corresponderia à investigação mais antiga.

Existe, não obstante, certo exagero em afirmar que a disciplina contemporânea de direito internacional originou-se, em sua inteireza, da doutrina medieval do direito da guerra. À exceção de Suárez e Grócio (pode incluir-se entre estes dois, não sem controvérsias, Vitória e, possivelmente, Vázques de Menchaca e Gentili), o conceito de jus gentium dos autores da tradição da guerra justa não equivale a um direito entre os povos, mas a um direito nacional comum, e ainda se encontraria imerso na órbita romana de Ulpiano - mencionada a seguir. Boa parte desses escritores cristãos nem mesmo apresenta a expressão "jus gentium". De acordo com uma imagem bastante sugestiva de Haggenmacher, parece possível comparar a evolução da doutrina da guerra justa para o direito internacional com o crescimento de uma

\footnotetext{
2 "Le moyen âge voit se former quelques institutions du droit de gens, mais elles sont trop chétives pour qu'on puisse em tenir compte. Seul, le droit de la guerre se développe sérieusement; il forme le noyeau du droit international." (NYS, Ernest. Le Droit de la Guerre et les précurseurs de Grotius. Bruxelles, Leipzig: Murquardt, 1882. p. 7). Confira, a título de ilustração, além da recém citada, outra obra que estabelece a origem do direito internacional no direito de guerra: VANDERPOL, Alfred. La Doctrine Scolastique du Droit de Guerre. Paris: A. Pedone, 1919.
} 
planta: se este corresponde a uma flor, o desenvolvimento do direito da guerra se identifica com o caule. ${ }^{3}$

Quando Aristóteles introduz, no livro V da Ética a Nicômaco, a sua conhecida distinção entre justo natural e justo legal ${ }^{4}$, também legou à posteridade (sobretudo à sua interpretação pela Escolástica) a noção de que o direito natural seria imutável, e o direito positivo variável de lugar para lugar. Um apresenta uma feição universal, o outro particularista. Um encontra-se radicado na verdade, na essência eterna das coisas, o outro na opinião, na doxa, tão inconstante como as circunstâncias humanas.

Entretanto, essa bipartição teria vida curta. Um terceiro termo seria incluído: o direito das gentes. Esse ramo reuniria elementos dos outros dois, seria positivo, mas aplicável a todos os homens. Para um internacionalista contemporâneo, a natureza desse direito não constitui um problema: a sua característica de universalidade não deriva da razão natural; trata-se tãosomente de âmbito de validade espacial que cobre todos os Estados. Mas essa aparente simplicidade revela-se enganadora. A verdade é que o direito das gentes constitui um tertius genus, um meio-termo entre o direito natural e o direito positivo. $\mathrm{O}$ conceito de direito das gentes só se aproxima do de direito internacional quando passa a designar mais do que uma realidade "extranacional"; não só um direito que ultrapassa as fronteiras do Estado, mas que rege as relações entre os povos.

\section{A Concepção Romana}

O direito romano exerceu profunda influência sobre os autores de direito internacional. Até o século XVIII, além das fontes, Roma legou a todo o Ocidente, inclusive ao Reino Unido, uma terminologia jurídica comum. Sempre que possível os autores se serviam do vocabulário e das fontes romanas. Em verdade, essas referências nada diziam sobre o direito internacional, mas constituíam uma tradição - bem como uma fonte de inspiração obrigatória. As normas sobre a propriedade privada (dominium), por exemplo, foram aplicadas sem a menor distinção para a soberania territorial; das regras sobre os contratos

\footnotetext{
${ }^{3}$ Cf. HAGGENMACHER, Peter. La place de Francisco de Vitoria parmi les fondateurs du droit international. In: TRUYOL y SERRA, Antonio et al. Actualité de la Pensée Juridique de Francisco de Vitoria. Bruxelles: Bruylant, Centre Charles De Visscher pour le droit international, 1988. p. 77.

${ }^{4}$ Cf. ARISTÓTELES. Ética a Nicômaco. Trad. Leonel Vallandro e Gerd Bornheim. São Paulo: Abril Cultural, 1973. p. 331. livro V, 7.
} 
internos se aduziram os tratados internacionais; as disposições sobre o mandatum se estenderam às funções dos agentes diplomáticos. ${ }^{5}$

Do mesmo modo, o conceito de direito das gentes é tomado dos romanos: corresponde à tradução literal de jus gentium. Surge primeiro em Roma, durante a organização tribal, mesmo antes da monarquia - que foi instituída ao mesmo tempo em que a Cidade, em 754 a.C. - com um significado bastante diferente de direito internacional. A organização social da península itálica baseava-se, nesses princípios, num sistema denominado "gentílico", porque constituía o direito das "gens", das pessoas que pertenciam ao mesmo clã ou a clãs aparentados. Era possível distinguir entre "o jus gentilicum que regia as relações entre as classes superiores e as inferiores no seio de uma mesma gente, o jus gentilitatis que compreendia as leis em vigor no seio da classe superior dos gentis e o jus gentium que regulava as relações entre as diferentes gentes" ${ }^{\prime}$. A gens representava tanto a fonte normativa como o fato jurídico por excelência; as normas jurídicas originavam-se e destinavam-se à gens romana.

Mais tarde, o jus gentium romano passou a aplicar-se àquelas relações entre os estrangeiros (peregrini) entre si e com os cives romanos. Tratava-se de um conjunto de ordenações cujos destinatários eram seres humanos, não organizações políticas. Além disso, consistia num direito intra gentes, não inter gentes. A partir de 242 a.C., era ministrado por um praetor peregrinus, uma figura itinerante; fator que permitiu que seus editos pudessem harmonizar propostas culturais e tradições jurídicas distintas. O pretor precisava, pois, privilegiar os acordos reais, não os vínculos formais, a substância, em vez da forma, pois esta é própria de uma só comunidade e não se pode universalizá-la com facilidade. Nos contratos, deveria privilegiar a volutas, o consensus, ainda que a forma fosse precária. Essa qualidade destaca-se do restante do direito romano, formalista por essência. Mesmo nos seus primórdios, já se delineia a tarefa fundamental desse ramo: "governar as relações entre os 'estranhos', entre seres que não pertencem à mesma tribo, ao mesmo clã, à mesma nação, à mesma cultura, mas que compartilham somente uma humanidade comum"7. O jus gentium encerra consigo a exigência de um direito universal, de um direito que deveria ser, em

\footnotetext{
${ }^{5}$ Cf. NUSSBAUM, Arthur. Historia del Derecho Internacional. Trad. Francisco Javier Osset. Madrid: Revista de Derecho Privado, 1953. p. 14.

6 “(...) le jus gentilicium qui gouvernait les relations entre les classes supérieures et les classes inférieures au sein d'une même gente, les jus gentilitatis qui comprenait les lois en vigueur aun sein de la classe supérieure des gentils et le jus gentium qui réglait les rapports entre les différents gentes" (LAGHMANI, Slim. Histoire du droit des gens: du jus gentium impérial au jus publicum europaeum. Paris: Pedone, 2003. p. 11).

7 “'(...) gobernar las relaciones entre 'extraños', entre seres que no pertenecen a la misma tribu, al mismu clan, a la misma nación, a la misma cultura sino que comparten sólo una común humanidad" (VIOLA, Francesco. Derecho de Gentes Antiguo e Contemporáneo. Trad. Isabel Trujillo. Persona y Derecho, n. 41, 2004, p. 166).
} 
princípio, aceito por todos os homens, deveria ser um ramo não nacional, mas aberto à diferença.

Esse ramo pertencia, de fato, ao direito positivo, mas diversos elementos o aproximavam do direito natural. Como o orgulho romano impedia que se adotasse, de maneira direta, regras jurídicas externas, o jus gentium recepcionava e re-elaborava os usos e costumes dos outros povos. Introduziu-se assim um corpo de jus aequum, que pouco tem a ver com a doçura ou a mitigação dos rigores da lei - conforme uma definição bastante corrente, no Brasil, de eqüidade. Tratava-se antes de uma preferência pela vontade real, em vez de uma fórmula instrumental; uma exigência de universalidade para favorecer a comunicação. Ademais, a noção de bona fides, de fidelidade com a palavra empenhada, ocupava posição central. A boa fé revela-se fundamental para a estabilidade e a perenidade das relações comerciais e constitui uma garantia de credibilidade pessoal. Além de relações comerciais, Roma estabelecia com os estrangeiros relações de patronato, amicitia e hospitium. O jus gentium, assim, ocupava-se também da preservação dos mores. Esses conteúdos éticos tornavam o direito das gentes mais próximo do direito natural do que do direito positivo. ${ }^{8}$

Dessa feita, como o jus gentium apresentava-se como um conjunto de normas universais, com um processo de formação bastante vinculado ao do costume - o qual se perde em tempos imemoriais -, não se deve estranhar o fato dele ter sido, não raro, confundido com o próprio direito natural. Cícero mesmo não faz distinção entre o jus naturalis e o jus gentium. No De Officiis, ele investiga a natureza das obrigações que proíbem prejudicar o próximo: "Ora, por certo isso não se dá apenas por força da natureza, isto é, pelo direito das gentes, mas também em virtude das leis dos povos, que sustentam a coisa pública em cada cidade. Elas preceituam igualmente que não é lícito prejudicar os outros em benefício próprio." Adiante, Cícero demonstra a validade dessa lei mesmo diante da torpeza dos costumes e a corrupção da lei civil:

\footnotetext{
Embora eu constate que semelhante embuste não é considerado torpe em virtude da perversão dos costumes, nem é proibido pela lei ou o direito civil, creio que a lei da natureza o proíbe. Com efeito, existe uma sociedade - já se disse muitas vezes, mas convém repeti-lo outras muitas - bastante ampla, a sociedade de todos os homens; uma mais restrita, a dos que integram a mesma família, e, por fim, uma ainda menor, as dos que são da mesma cidade. Quiseram, pois, nossos antepassados que existisse, por um lado, o direito dos povos, por outro, o direito civil. O direito civil não precisa ser necessariamente o direito dos povos, mas o direito dos povos precisa ser necessariamente o direito civil. ${ }^{9}$
}

\footnotetext{
${ }^{8}$ Cf. VIOLA, Francesco. Op. Cit., p. 170.

9 "Neque vero hoc solum natura, id est jure gentium, sed etiam legibus populorum, quibus in singulis civitatibus respublica continetur, eodem modo constitutum est, ut non liceat sui commodi causa nocere alteri." E, adiante: "Hoc quanquam video propter depravationem consuetudinis neque more turpe haberi neque aut lege sanciri aut jure civilii, tamen natura elege sancitum est. Societas enim est (quod etsi saepe dictum est, dicendum tamen est
} 
Perceba-se que o direito civil, o direito da cidade, encontra-se contraposto ao direito das gentes, o direito que decorre da natureza, da ampla sociedade dos homens. Todo direito origina-se de uma sociedade: o direito civil, de uma sociedade pequena que é a própria cidade, e o direito das gentes de uma magna communitas humana, a sociedade de todos os homens. Os pensadores romanos, influenciados pela filosofia estóica, ao confrontar o direito civil com o direito das gentes, promoviam generalizações que alteravam de maneira significativa o conteúdo do termo. O jus gentium histórico dos romanos utilizava a experiência estrangeira em casos muito particulares; contudo, o jus gentium filosófico compreendia normas e instituições jurídicas que se encontravam por todas as partes, como, entre outras, as relativas ao matrimônio, à defesa e à proteção da propriedade, às obrigações de reparar o dano. Tratava-se, pois, de um direito universal comum, o que dificultaria muito a distinção com o direito natural.

Os grandes juristas romanos também apresentavam essa indeterminação. Nas compilações, eles não se limitavam a arrolar os institutos do direito das gentes, mas também buscavam defini-lo, e era a filosofia grega, não a prática jurídica corrente, que servia de matriz. Cumpre salientar que, entre as diversas matérias reguladas por esse jus gentium filosófico, algumas possuíam caráter internacional, como o direito de legação e as regras sobre o botim e os despojos de guerra, mas a maior parte concentrava-se no direito privado, acrescido de alguns temas de direito público interno, como o status dos deportados. Ainda não se mostra possível, portanto, estabelecer qualquer correlação com o direito internacional. No Digesto, o seu título inicial comporta duas definições principais de jus gentium, uma de Gaio e a outra de Ulpiano; ambas remetem o ramo a um fundamento natural. Para Gaio,

\footnotetext{
Em todos os povos que são regidos pelas leis e pelos costumes, serve-se tanto do direito que lhes é próprio, como do direito que é comum a todos os homens. Com efeito, o direito que cada povo estabeleceu para si é próprio à cidade ela mesma; mas o direito que a razão natural estabeleceu entre todos os homens é uma regra segundo a qual todos observam igualmente e se chama direito das gentes, na medida em que é o direito que todas as nações se servem. ${ }^{10}$
}

saepius), latissime quidem quae pateat, hominum inter homines, interior eorum, qui ejusdem gentis sunt, propior eorum qui ejusdem civitatis. Itaque majores aliud jus gentium, aliud jus civile esse voluerunt. Quod civile, non idem continuo gentium; quod autem gentium, idem civile esse debet." (CICERÓN. De Officiis. Paris: Garnier, s/d. Liber III, V e XVII. A tradução utilizada foi a da Martins Fontes: CÍCERO, Marco Túlio. Dos Deveres. Trad. Angélica Chiapeta. São Paulo: Martins Fontes, 1999. p. 136 e 157).

10 "Omnes populi, qui legibus et moribus reguntur, partim suo proprio, partim communi omnium hominum iure utuntur nam quod quisque populus ipse sibi ius constituit, id ipsius proprium civitatis est vocaturque ius civile, quasi ius proprium ipsius civitatis: quod vero naturalis ratio inter omnes homines constituit, id apud omnes peraeque custoditur vocaturque ius gentium, quasi quo iure omnes gentes utuntur." (IUSTINIANUS IMPERATOR. Corpus Iuris Civilis. ed. Krueger e Mommsen. Berlim: Weidmann, 1908. Digesto, 1, 1, 9). 
Há, portanto, duas categorias de normas: o direito civil e o direito das gentes. Aquele é próprio de cada Estado, que é também seu autor; este é comum a todos os homens e se manifesta de forma igual em todos os povos. Os povos não o criam, ele decorre de um princípio superior, a naturalis ratio. Trata-se de um direito anterior ao direito positivo, originado num estado de inocência primitiva. Percebe-se, de maneira clara, a oposição entre o direito de um povo e aquele comum a todos os povos, um direito baseado na vontade humana e outro decorrente da reta razão, um direito escrito e outro não-escrito. Não há, pois, problema algum em substituir a expressão jus gentium pela de direito natural.

Ulpiano, por sua vez, acrescenta um terceiro termo a essa divisão das fontes: jus naturale. Sua exposição principia por este nome, o qual compreende as funções vitais mais elementares - a união dos sexos, a procriação, a educação da prole - que a natureza reserva a todos os seres vivos, humanos ou animais. Esse jus naturale parece remontar à lei natural dos estóicos. Por oposição a esse conceito, o autor define o direito das gentes: "O direito das gentes é aplicado às gentes humanas, que por meio do entendimento pode depreender facilmente da natureza, e, entre todos os animais, apenas o homem compartilha [essa lei] entre si." ${ }^{11}$ O direito das gentes constitui a porção do direito natural que se aplica somente aos seres humanos.

Essa divisão remonta a uma concepção pitagórica que pressupõe a existência de uma idade de inocência, uma era de ouro, a qual se contrapõe a uma idade do pecado, uma era de ferro. Nos tempos antigos, tudo seria comum, o homem seria livre e se encontraria inserido de modo direto na natureza. Depois, haveria seguido a perversão e o egoísmo, e teria instauradose a propriedade privada e outras instituições excludentes. Em Ulpiano, o direito natural corresponde ao período idílico, e o direito das gentes o período posterior. ${ }^{12}$

Apesar da inserção desse terceiro termo, tanto Ulpiano como Gaio consideram consoante os ensinamentos de Aristóteles - o direito civil um ius proprium, e o opõe a um ius commune. A analogia ao estagirita revela-se, de fato, imperfeita, pois, se em Gaio o direito comum equivale ao direito das gentes, em Ulpiano o ius commune seria o direito das gentes e também o direito natural. Neste autor, tudo o que não for direito civil é direito comum. Portanto (com a insistência na analogia), uma vez que o direito civil mostra-se particular e

\footnotetext{
11 "Ius gentium est, quo gentes humanae utuntur, quod a naturali recedere facile intellegere licet, quia illud omnibus animalibus, hoc solis hominibus inter se commune sit." (IUSTINIANUS IMPERATOR. Corpus Iuris Civilis. ed. Krueger e Mommsen. Berlim: Weidmann, 1908. 1, 1, 1, 4).

${ }^{12}$ Cf. BARCIA TRELLES, Camilo. Francisco Suárez: les théologiens espagnols du XVIe siècle et l'école moderne du Droit International. Recueil de Cours de l'Académie de Droit International de Le Hague, 1933, n. 1, t. 43, Paris: Sirey, p. 424.
} 
mutável, o jus gentium compartilharia com o jus naturale a sua imutabilidade. Caso essa característica se imponha aos homens em virtude de um princípio superior, como a razão natural de Gaio, então o direito das gentes de Ulpiano não pertenceria ao direito positivo e não corresponderia à realidade histórica do jus gentium romano. Possuiria apenas uma natureza filosófica e helênica. Para evitar essa conclusão, a característica "comum" do direito das gentes de Ulpiano precisaria derivar de uma coincidência de institutos jurídicos entre os diversos povos. Ou Ulpiano seria um mau jurista, por não descrever o jus gentium histórico com a devida acuidade, ou seria um mau filósofo, por desconhecer os fundamentos da bipartição aristotélica.

Em qualquer uma das interpretações, deve constatar-se que nem o jus gentium de Ulpiano nem o de Gaio assemelham-se ao direito internacional contemporâneo. Ainda que se apliquem aos mais diferentes povos, os verdadeiros sujeitos não são as gentes ou os populi que os autores mencionam. Como no direito civil e no direito natural, os sujeitos são os indivíduos. Em Ulpiano, a tônica repousa sobre o adjetivo humanae; o emprego do substantivo gentes, em vez de genus humanum - expressão a qual, deve salientar-se, foi empregada mais acima no texto -, serve para manter o jogo de palavras com o termo jus gentium e o valor probatório do qual ele supostamente deriva. O mesmo ocorre com Gaio. O termo populi não equivale ao sujeito do jus gentium nem em direito nem na sintaxe, pois o apud inserido no final o torna um complemento de lugar. Além disso, convém ressaltar a repetição de omnes, que aparece quatro vezes na frase. "Longe de ser ius inter gentes ou inter populos, o direito das gentes dos nossos dois autores deve ser entendido como inter homines" ${ }^{\prime 13}$. Os indivíduos são os sujeitos; mais precisamente os homens livres, por causa da oposição ao direito civil que se dirige aos homens que possuem, além da liberdade, o status civitatis.

\section{A Concepção Medieval}

O conceito de direito natural de Ulpiano, próprio tão-somente aos animais, iria sofrer repúdio pelos autores do Medievo. Concomitante a essa repulsa, iria surgir também o problema da individualidade do direito das gentes. Como visto, a Concordia de Graziano constitui um marco para tratar do direito da guerra. Da mesma forma, ela enuncia uma

\footnotetext{
13 "Loin d'être ius inter gentes ou inter populos, le droit des gens de nos deux auteurs doit s'entendre inter homines" (HAGGENMACHER, Peter. Grotius et la doctrine de la guerre juste. Genève, Paris: Heige, Presses Universitaires de France, 1983. p. 318).
} 
definição de jus gentium extraída de Santo Isidoro que haveria de se tornar célebre. No capítulo II das Etymologiae, o arcebispo de Sevilha, Santo Isidoro, procede a uma distinção bastante interessante entre leis humanas e divinas. Estas decorrem da natureza, aquelas dos usos; por essa razão, as leis humanas são variáveis de lugar para lugar, conforme a vontade dos povos, enquanto as divinas são imutáveis. Cumpre salientar que lex, para Santo Isidoro, não significa jus; aquele termo constitui, ao lado de mores, espécie deste. O jus divide-se em natural, civil e das gentes, como uma categoria à parte. $\mathrm{O}$ direito civil é o direito positivo da cidade, e o direito natural destina-se somente aos homens. Resta definir o jus gentium. Sem defini-lo propriamente, o autor principia por indicar sua origem etimológica e recorda o conceito de Gaio, mas introduz uma sutil diferença: o direito das gentes apresenta-se "quase" universal. Então, enumera os institutos do qual este ramo se ocupa:

O direito das gentes trata da ocupação, da edificação e da fortificação de castelos e cidades, da guerra, dos cativos de guerra, da escravidão, da recuperação de direitos pelo postliminium, dos acordos de paz, das tréguas, da inviolabilidade das embaixadas, e da proibição do casamento entre pessoas de religiões diferentes. E é assim o direito das gentes, pois é a lei dos usos de todas as gentes. ${ }^{14}$

A definição por meio da enumeração dos institutos já indicava uma tendência posterior que iria culminar na autonomia do jus gentium face à ratio naturalis. $\mathrm{O}$ modo medieval de se fazer jurisprudência - ciência do direito -, denominado de mos italicus por causa da influência de juristas como Baldo, Paulo Castrensis e Bártolo de Sassoferrato, consistia na redação de longos tratados sobre tudo o que havia para se conhecer do Direito de então. Os primeiros manuais apenas ressuscitavam o direito romano - o qual se considerava o pináculo da perfeição em termos jurídicos -; a seguir, principiou-se a combinar o legado romano com as instituições germânicas. Havia, pois, uma acentuada característica universalista (ainda que, por universal, se entenda européia), e, de maneira bastante vagarosa, é que começou a despontar uma ou outra obra que versasse sobre temas do direito civil, interno a um só povo. Discorria-se por meio de topói e de questões formuladas pelos autores que já haviam escrito sobre o tema. Aos poucos, os tratados passaram a versar sobre questões jurídicas específicas, embora conservassem ainda a abordagem antiga. ${ }^{15} \mathrm{Na}$ área que seria o direito das gentes,

\footnotetext{
14 “Ius gentium est sedium occupatio, aedificatio, munitio, bella, captivitates, servitutes, postliminia, foedera, pacis, indutiae, legatorum non violandorum religio, conubia inter alienigenas prohibita. Et inde ius gentium, quia eo iure omnes fere gentes utuntur." ISIDORUS HISPALENSIS EPISCOPUS. Etymologiarum sive Originum Libri XX. ed. W. M. Lindsay. Oxford: Claredon Press, 1911. V, VI).

${ }^{15}$ Tratava-se da Retórica, considerada uma verdadeira vir civilis, uma virtude cidadã. A Lógica destinava-se somente à filosofia especulativa e à Teologia, que era a magna ciência. Santo Tomás, v.g., insere esta, consoante a conhecida gradação do conhecimento exposta pelo Estagirita no capítulo I do livro I da Metafísica, no cume da hierarquia, pois seria uma disciplina mais especulativa do que prática e, ainda, superior às demais. Cabe lembrar que o próprio Aristóteles havia estabelecido a Metafísica no topo da hierarquia, mas ela se chama de Metafísica
} 
surgem diversas monografias sobre o direito das embaixadas, sem mencionar os livros da tradição da guerra justa. ${ }^{16}$

Alguns autores ${ }^{17}$ notam a semelhança entre a "definição" isidoriana e a moderna disciplina de direito internacional. Longe de ser fortuita, essa enumeração delimitaria três grandes círculos temáticos: um concernente à instituição do poder político, outro à guerra e às suas conseqüências e o terceiro ao direito dos tratados e das embaixadas. Cumpre salientar que, de fato, alguns institutos já assemelham o direito das gentes de Isidoro ao direito internacional contemporâneo. Contudo, outros - como é o caso das núpcias interditas aos estrangeiros - causariam espécie a um internacionalista. Este último, ainda, escapa a qualquer um dos círculos.

Outros autores $^{18}$, contudo, não encontram no jus gentium isidoriano qualquer vestígio de direito internacional. Embora Isidoro rejeite a definição de Ulpiano de direito natural, quando decide abordar o direito das gentes, sua imaginação não o conduz a outras paragens. $\mathrm{O}$ bispo de Sevilha teria apenas "esbarrado" no termo jus gentium, por causa da autoridade que os textos antigos haviam adquirido, e, assim, ele precisaria deter-se sobre o tema sob pena de seu texto tornar-se incompleto.

A vagueza do texto permite, até mesmo, uma especulação que Francisco Suárez fará anos depois com a sua conhecida divisão de jus inter gentes e jus intra gentes. O direito das gentes de Isidoro equivaleria a este último, uma espécie de direito privado comum aos povos. O adjetivo "comum" é proveniente de uma mera coincidência, e não de uma determinação que obriga a todos os Estados, o que, de qualquer modo, não deixa de constituir uma diferença em relação ao jus gentium romano. Já são normas criadas pelo engenho humano - os usos, o costume: eo iure omnes fere gentes utuntur -, como o direito civil, e aplicáveis aos mais diferentes povos e homens, como o direito natural.

Ainda assim, parece duvidoso que Isidoro haja distanciado-se de todo da órbita romana, uma vez que boa parte dos seus institutos coincidem com os do jus gentium helênico

somente quando aborda o ens commune; "'filosofia primera', en cuanto considera las causas primeras de las cosas; 'teologia', en cuanto considera las sustancias que no tienen materia, Dios, etc" (SCIACCA, Michele. Perspectiva de la metafisica en Sto. Tomas. Madrid: Speiro, 1976. p. 50). É o tríplice aspecto de uma única disciplina. Todavia, as ciências práticas, como a Ética e o Direito, que visam o bem viver, não são expressas de acordo com os cânones da Lógica formal, mas conforme outra lógica que procura o convencimento e a persuasão: a Retórica e a Tópica.

${ }^{16}$ Cf. WIJFFELS, Alain. Early-Modern Literature on International Law and the Usus Modernus. Grotiana, v. 16-17, 1995-1996, p. 39.

${ }^{17}$ Cf. RIVIER, Alphonse. Note sur la littérature du droit de gens avant la publication du Jus Belli ac Pacis de Grotius (1625). Bruxelles: Académie Royale de Belgique, 1883. pp. 9-10.

${ }^{18} \mathrm{Cf}$. WALKER, Thomas Alfred. A History of the Law of Nations. Cambridge: Cambridge University Press, 1899. v. I. § 85 . 
dos juristas romanos. Como o direito das gentes não ocupava o centro das atenções do autor, revela-se provável que o termo aludisse à realidade jurídico-política da Alta Idade Média: uma cristandade européia bastante dividida, governada pelo papa e pelo imperador - uma autoridade mais simbólica do que efetiva -, unida por uma vaga comunhão de interesses e por um direito positivo consuetudinário comum, as reminiscências do direito romano. Isso poderia explicar o caráter positivo do direito das gentes isidoriano, sem distanciá-lo das fontes antigas.

Assim se apresentava o problema da autonomia do direito das gentes: o ramo contém institutos quem emanam da vontade humana, mas compartilha uma (quase) universalidade com o direito natural, o que remete ao problema de sua fundamentação. Em Ulpiano, ele constitui uma espécie do gênero direito natural, mas ele abrange normas de direito positivo.

Os glosadores procuraram resolver essa questão ao cindir o direito natural ou o direito das gentes em diversas espécies. Isso obedecia a uma idéia de desenvolvimento progressivo do direito natural ao direito positivo num quadro temporal e genético. Assim, encontra-se na Summa Institutionum de Placentino um prima iura naturalia e um secunda iura naturalia, que correspondem, respectivamente, ao direito natural e das gentes. Etienne de Tournay, na Summa ad decretum, menciona, da mesma forma, um ius naturale primitivum, anterior à instituição da propriedade privada; esta própria do jus gentium. Diversas glosas relativas às Institutas distinguem um jus gentium criado junto com o homem, e outro criado por este: o primeiro se inspira em Gaio, e o segundo equivale ao direito das gentes positivo. ${ }^{19}$

Esse tipo de solução iria perdurar até Grócio; ela, de fato, possibilita conceder um conteúdo a uma noção que perambulava entre dois extremos. Entretanto, apenas esconde o problema da autonomia do jus gentium positivo face ao jus naturale e ao jus civile e ainda cria outro: o de uma subdivisão desnecessária. Revela-se desnecessário observar que este jus gentium em nada se parece com o direito internacional.

Ao contrário dos juristas, legistas ou canonistas medievais, os teólogos ignoraram o direito das gentes. As Sentenças de Pedro Lombardo, bem como os comentários e as sumas dos teólogos posteriores ao século XIII, silenciam sobre o tema. Se, vez por outra, ocorre uma menção, o jus gentium desempenha apenas uma função ornamental. ${ }^{20}$

A exceção é Santo Tomás de Aquino que atribui ao jus gentium um lugar privilegiado no seu pensamento e reúne toda a interpretação tradicional num conceito só. O Aquinate, cabe salientar, tal como Santo Isidoro, diferencia Direito de lei. O Tratado das Leis deve ser lido em conjunto com o Tratado da Graça, pois tanto as leis como a graça constituem princípios

\footnotetext{
${ }^{19}$ Cf. HAGGENMACHER, Peter. Grotius et la doctrine de la guerre juste. p. 326.

${ }^{20} \mathrm{Cf}$. HAGGENMACHER, Peter. Grotius et la doctrine de la guerre juste. p. 327.
} 
externos ao homem que regulam o seu comportamento e o movem para a retidão. O estudo do Direito insere-se, no Doutor Angélico, no Tratado da Justiça; o objeto de análise da virtude justiça é o próprio Direito, o iustum que corresponde ao dikaión aristotélico. Estudar as diferentes espécies de lei em Santo Tomás (lei eterna, lei natural, lei divina, lei humana) significa investigar o projeto ordenador de Deus para a criação, porque "a lei é uma certa regra e medida dos atos segundo a qual alguém é induzido a agir ou coibido de fazer algo" 21 . A lei não visa regular apenas a organização societária humana, mas todo o universo. Por sua vez, o problema todo do Direito resume-se à justiça. Trata-se de uma questão que um positivista moderno, como Kelsen, situaria fora dos domínios do estudo do Direito, mas não um jurista medieval e muito menos um teólogo.

Haggenmacher afirma que Santo Tomás apresenta duas concepções diferentes de jus gentium: uma no Tratado das Leis e a outra no Tratado da Justiça. A diferença não se resumiria à diversidade de enfoque de um e do outro tratado. No primeiro, o Doutor Angélico retomaria a definição de Santo Isidoro - segundo a qual o direito das gentes pertenceria ao direito positivo -, e, no último, ele reconstruiria a dos romanos - para quem o ramo em questão se confunde com o direito natural. Uma vez que as duas noções não são compatíveis, a unificação proposta pelo Aquinate restaria ambígua. ${ }^{22}$ Todavia, a conclusão de Haggenmacher não resiste a uma análise mais aprofundada. Uma inversão na ordem de exposição dos dois textos (primeiro o Tratado da Justiça, depois o das Leis) pode auxiliar a compreender melhor a proposta sintética do dominicano.

Em Santo Tomás, como no Estagirita, o Direito (jus) pode proceder tanto da natureza das coisas (direito natural), como de uma convenção (direito positivo). Assim, o autor põe-se a questão de como diferenciar o direito das gentes do direito natural. O justo natural é aquilo que, por sua natureza, está "ajustado" ao outro. E isso ocorre de dois modos:

\footnotetext{
Primeiro, considerando a coisa absolutamente em si mesma; assim o macho, por sua natureza, acomoda-se à fêmea para procriar com ela, e os pais ao filho, para alimentá-lo. Segundo, considerando a coisa não absolutamente, em sua natureza, mas em relação às suas conseqüências; por exemplo, a propriedade das possessões [de um terreno]. ${ }^{23}$
}

\footnotetext{
21 “(...) lex quaedam regula est et mensura actuum, secundum quam inducitur aliquis ad agendum, vel ab agendo retrahitur (...)" (AQUINO, Santo Tomas de. Suma Teologica. Texto latino de la edición crítica Leonina. Trad. Francisco Barbado Viejo, O.P. 2. ed. Madrid: Biblioteca de Autores Cristianos, 1947. 1-2 q. 90 a.1).

${ }^{22} \mathrm{Cf}$. HAGGENMACHER, Peter. Grotius et la doctrine de la guerre juste. p. 328.

23 "Uno modo, secundum absolutam sui considerationem: sicut masculus ex sui ratione habet commensurationem ad feminam ut ex ea generet, et parens ad filium ut eum nutriat. Alio modo aliquid est naturaliter alteri commensuratum non secundum aliquid quod ex ipso consequitur: puta proprietas possessionum." (AQUINO, Santo Tomas de. Op. Cit., 2-2 q. 57 a. 3).
} 
O direito natural, em si mesmo, já se encontra ajustado ao outro: a procriação é justa por natureza porque mulher e homem possuem órgãos reprodutivos que se compatibilizam perfeitamente, e o cuidado com a prole também se revela justo por natureza porque a mãe possui leite materno para alimentar o filho. O ajuste perfeito corresponde à evidência: ela se basta, não requer nenhuma comprovação. Santo Tomás denomina isso de direito natural primo modo.

Todavia, algo, pela sua própria natureza, também pode vir a tornar-se justo, caso não o seja de imediato. O exemplo da propriedade revela-se bastante ilustrativo. De fato, de um terreno em si, não decorre necessidade alguma dele pertencer a esta ou àquela pessoa. Contudo, ao se considerar as suas conseqüências - o fato de poder ser cultivado -, pode extrair-se o título dominial: esta, não aquela outra pessoa, é quem tem vocação para agricultor, e é justo que ela possua o terreno. Este tipo de justiça não escapa dos domínios do direito natural, porque não há nenhuma convenção humana que determine isto ou aquilo. Mas a virtude não decorre da coisa em si mesma: fez-se necessária uma intervenção humana - o cultivo do terreno - para perfectibilizá-la. Santo Tomás chama isso de direito natural secundo modo ou direito das gentes.

Cabe observar que as expressões primus e secundus modus aplicadas ao direito natural podem lembrar as concepções dos glosadores, mas o autor não as confere nenhuma característica temporal ou genética. Constituem apenas modos de adequação, conforme a natureza, de uma coisa a outra.

Perceba-se que o homem compartilha o direito natural primo modo com os demais animais. Já o direito natural secundo modo é exclusivo do ser humano. Trata-se, sem dúvida, da concepção de Ulpiano. Porém, Santo Tomás inseriu o jus gentium no direito natural; interpretou, assim, o direito das gentes de Ulpiano como parte do direito natural, não conforme uma outra interpretação segundo a qual ele corresponderia a um direito positivo comum. Ou isso, ou o Aquinate conciliou as duas fontes romanas: utilizou-se de Ulpiano para definir o direito natural, e de Gaio para o direito das gentes. Em ambas as possibilidades, o jus gentium parece pertencer à natureza e proceder da razão humana.

Ocorre que a redação do artigo terceiro da questão 57 do Tratado da Justiça se apresenta confusa. Santo Tomás, ao valer-se do método escolástico, nos questionamentos, menciona tão-somente a dicotomia direito natural / direito positivo, sem antever qualquer possibilidade de nuança. Como, em nenhum momento da resposta, afirma expressamente a naturalidade do direito das gentes, e já que ele distingue dois modos de "ajuste" de uma coisa a outra, o direito das gentes parece ser algo bastante distinto do direito natural. E o outro lado 
da equação só poderia ser o direito positivo. Por essa razão, até o momento, a hipótese de Peter Haggenmacher parece confirmar-se. O fato desse ajuste acontecer "de acordo com a natureza" pode perder-se em meio à falta de explicitação do raciocínio.

A análise, porém, não pode deter-se aqui. Deve buscar-se, no Tratado das Leis, o conceito de lei. Lei, em Santo Tomás, não representa um dever ser, mas uma medida, um padrão de referência, um projeto ordenador da razão. São medidas pelas quais se pautam tanto o movimento dos astros, o curso dos rios, como o instinto dos animais e a vida humana em sociedade. Não se trata de um comando normativo, mas de um projeto racional que organiza os diferentes planos de existência do universo. Cada espécie de lei (eterna, natural, civil) incide numa esfera própria de atuação, mas todas consistem numa mesma realidade: a ordenação da razão. A lei civil, por exemplo, não difere em substância da lei eterna, pois ambas representam ordenações da razão divina (embora, na lei civil, haja a co-causalidade da razão humana); uma aplicada a todo o cosmos, e a outra à vida humana na cidade. Este projeto de organização divina aplica-se de uma forma escalonada aos diversos domínios da realidade: a lei eterna constitui o plano de Deus para toda a criação e procede diretamente dEle. Já a lei natural é a própria participação da lei eterna nos seres racionais. E a lei positiva decorre, de modo lógico, da lei natural.

(...) a força da lei depende do grau da sua justiça. E, em se tratando das coisas humanas, sua justiça está em proporção com a sua conformidade com as regras da razão. E a primeira norma da razão é a lei natural, como já foi dito. Assim, toda lei humana terá caráter de lei na medida em que decorre da lei da natureza. ${ }^{24}$

Não apenas as diferentes espécies de lei guardam relações entre si; o próprio direito humano (o jus) decorre da lei (a lex) natural. O jus guarda relações com a lex. Todo o direito positivo, tanto o civil e como o das gentes, deriva da lei natural, mas de modo distinto. $\mathrm{O}$ primeiro provém per determinationem, e o segundo per conclusionem (1-2 q. 95 a. 4):

\footnotetext{
Mas deve notar-se que uma coisa pode derivar-se da lei natural de dois modos: primeiro, como as conclusões derivam de um princípio; segundo, por meio de determinação, como as determinações de certas noções comuns. O primeiro modo assemelha-se ao das ciências, as quais dos princípios se extraem conclusões demonstrativas. O segundo assemelha-se com o que ocorre nas artes: as formas abstratas materializam-se em algo particular; o arquiteto, por exemplo, materializa a forma genérica da casa neste ou naquele modelo de casa. ${ }^{25}$
}

\footnotetext{
24 "Unde inquantum habet de iustitia intantum habet de virtute legis. In rebus autem humanis dicitur esse aliquid iustum ex eo quod est rectum secundum regulam rationis. Rationis autem prima regula est lex naturae, ut ex supradictis patet. Unde omnis lex humanitus posita intantum habet de ratione legis, inquantum a lege naturae derivatur" (AQUINO, Santo Tomas de. Op. Cit., 1-2 q. 95 a. 2).

25 "Sed sciendum est quod a lege naturali dupliciter potest aliquid derivari: uno modo, sicut conclusiones ex principiis; alio modo, sicut determinationes quaedam aliquorum communium. Primus quidem modus est similis ei quo in scientiis ex principiis conclusiones demonstrativae produnctur. Secundo vero modo simile est quod in
} 
A lei natural, portanto, determina os limites morais que o direito civil não pode ultrapassar. Assim como um arquiteto guarda em sua mente a noção de "casa" e a usa como modelo para construir a casa concreta, também a lei natural determina como um modelo a construção do direito civil. Mas a cor e a textura da casa não constam do projeto original, e há, pois, certa margem de discricionariedade. O mesmo não ocorre com o direito das gentes. Este deriva da lei natural como teoremas extraídos de um axioma lógico. A lei natural é sua premissa maior, e o direito das gentes a menor.

Aqui se encontra o elemento que permite harmonizar as concepções de jus gentium de Santo Tomás. A derivação per conclusionem do Tratado das Leis corresponde à adequação secundo modo do Tratado da Justiça. Ambas se referem a formas da lei natural "produzir" o direito das gentes, e a maneira se dá não pela coisa em si, mas pelas suas conseqüências ou as suas conclusões. A diferença de enfoque deve-se ao fato de, no Tratado das Leis, o Doutor Angélico pretende distinguir o direito das gentes do direito civil, e, no Tratado da Justiça, procura diferenciar os modos de expressão do direito natural. Não há dois conceitos distintos de jus gentium; existe tão-somente a diversidade de propósitos.

Cumpre salientar que o fato do Aquinate classificar o direito das gentes como positivo pode induzir o leitor ao erro. Em certo sentido, o direito das gentes revela-se bastante natural. "O direito das gentes, de certo modo, é natural ao homem, porque é algo racional, já que decorre da lei natural (...). Não obstante, ele se distingue da lei natural no aspecto em que esta é comum a todos os animais." 26 Mas por que Santo Tomás emprega o termo "positivo"? Porque o Doutor Angélico não o emprega na sua acepção usual; deve substituir-se a expressão por "humano". O direito das gentes consiste no direito natural humano: o seu fundamento é a razão natural, mas ele não se mostra evidente. Ele pressupõe certo esforço humano para derivá-lo de verdades outras que - estas sim - são evidentes. De qualquer maneira, ele não depende de uma positivação para existir, como o direito civil.

\footnotetext{
Ao supor uma intervenção da razão discursiva para deduzir aquilo que não aparece de forma imediata e absoluta para a inteligência, o direito das gentes tem algo de positivo, mas tomando o termo positivo num sentido muito amplo, que não é usual na terminologia teológica e no pensamento jurídico atual. O direito das gentes está constituído pelas conclusões deduzidas dos primeiros princípios, absolutamente evidentes, da lei natural. Há, portanto, um positivo esforço, embora muito fácil, para deduzir e determinar essas conclusões que estão muito próximas daqueles princípios
}

artibus formae communes determinantur ad aliquid speciale: sicut artifez formam communem domus necesse est quod determinet ad hanc vel illam domus figuram." (AQUINO, Santo Tomas de. Op. Cit., 1-2 q. 95 a.2).

26 "Ad primum ergo dicendum quod ius gentium est quidem aliquo modo naturali homini, secundum quod est rationalis, inquantum derivatur a lege naturali (...). Distinguitur tamen a lege naturali, maxime ab eo quod est omnibus animalibus commune." (AQUINO, Santo Tomas de. Op. Cit., 1-2 q .95 a.4). 
e, por isso, encontram-se ao alcance de todas as gentes. Porém, a força ou o a validade da obrigação, nestas conclusões, provém do mesmo direito natural que substancialmente elas contêm. (grifo no original). ${ }^{27}$

Observe-se o exemplo de um incontestável instituto de direito das gentes: reduzir o inimigo vencido à condição de escravo. Em certo sentido, trata-se de um preceito natural. Transformar o inimigo cativo em escravo revela-se menos cruel do que assassiná-lo fora de combate, e isso decorre logicamente do mandamento natural "não matarás". Além disso, acreditava-se que o homem poderia dispor de sua própria liberdade; nada obsta que ele a perca numa guerra, ou para saldar dívidas.

O direito das gentes, portanto, não é imediatamente natural, mas provém de preceitos naturais. Isso se deve ao fato de a lei natural produzir no homem três inclinações: uma primeira que concerne tudo aquilo que interessa para a conservação da vida; outra que o homem compartilha com os demais animais e que diz respeito à união dos sexos, à educação da prole, etc, e uma última que se apresenta propriamente racional e que se refere à tendência natural de conhecer as verdades divinas e a viver em sociedade. ${ }^{28} \mathrm{O}$ direito ou o justo natural propriamente dito procede das duas primeiras inclinações da lei natural, pois ele decorre de maneira absoluta, como o macho se ajusta à fêmea, consoante a transcrição acima do Tratado da Justiça. Já o direito das gentes decorre da terceira inclinação da lei natural; ele procede não de forma absoluta, mas de modo comparativo e consecutivo. Ele não brota da essência da coisa; exige a intervenção da razão humana. Por isso, ele é considerado humano: as suas conclusões são condicionais e hipotéticas, pois dependem do arbítrio dos homens, "mesmo que esse arbítrio não seja o de um poder particular ou de uma sociedade concreta, mas, em certo sentido, o de toda a humanidade, o de todas as gentes" ${ }^{, 29}$.

A concepção tomista revela-se confusa e complexa, mas nunca ambígua. O direito das gentes é sempre direito natural. Trata-se apenas de um direito natural apenas "menos evidente" do que o propriamente dito. Em verdade, não corresponde a um ramo distinto, mas

\footnotetext{
27 “Al suponer una intervención de la razón discursiva para deducir lo que no aparece inmediata y absolutamente a la inteligencia, el derecho de gentes tiene algo de positivo, pero tomando el término positivo en un sentido muy amplio, que no es usual en la terminología teológica y en el pensamiento jurídico atual. El derecho de gentes está constituído por las conclusiones deducidas de los primeros principios, absolutamente evidentes, de la ley natural. Hay, pues, un positivo esfuerzo, aunque muy fácil, para deducir y dictaminar esas conclusiones, que están muy próximas a los principios y por eso se hallan al alcance de todas las gentes. Pero la fuerza o vigor de obligación, en esas conclusiones, viene del mismo derecho natural, que substancialmente contienem." (SANTIAGO RAMIREZ. Introducción a las cuestiones 95-97. AQUINO, Santo Tomas de. Op. Cit. Tomo VI, p. 148).

${ }^{28}$ Cf. AQUINO, Santo Tomas de. Op. Cit., 1-2 q. 94 a.2.

29 “(...) aunque ese arbitrio no sea el de un poder particular o de una sociedad concreta, sino, en cierto sentido, de toda la humanidad, de todas las gentes" (SANTIAGO RAMIREZ. Introducción a las cuestiones 95-97. AQUINO, Santo Tomas de. Op. Cit. Tomo VI, p. 147).
} 
a um modo de derivação. Em Santo Tomás, o que o termo jus gentium ganhou em fundamentação e unidade perdeu em autonomia.

De imediato, as considerações do Aquinate sobre o direito das gentes não repercutem entre os teólogos. Seria necessário esperar até o século XVI para surgir um Francisco de Vitória. Mas os juristas medievais continuaram a comentar o Digesto e as Institutas e seguiram com a tradição dos glosadores de dividir o direito natural ou o das gentes em ius primaevum e secundum, conforme uma sucessão cronológica.

Bártolo de Sassoferrato divide o direito natural em dois, e separa também o direito das gentes em dois. O ius naturale secundum coincide com o ius gentium primaevum, aplica-se a todos os homens e decorre da ratio naturalis de Gaio. Já o ius gentium secundum corresponde a um direito comum a todos os povos e se origina das gentes mesmo. Esse tipo de desenvolvimento progressivo aparece também nos discípulos e seguidores de Bártolo, como Baldo de Ubaldo e Paulo de Castro. Essa terminologia sobrevive até o jovem Grócio, que vai empregá-la no De Jure Praedae. ${ }^{30}$ Importa ressaltar aqui que, embora ainda não haja conquistado autonomia, já começa a surgir a idéia de um direito das gentes propriamente positivo, que procede dos usus dos mais diversos povos, não da razão natural.

\section{A Concepção Vitoriana}

Do final do século XIII e início do século XIV até o século XVI, o problema da autonomia do jus gentium não havia progredido. Somente quando a Suma Teológica de Tomás de Aquino termina por suplantar de vez o Livro das Sentenças de Pedro Lombardo, como manual de estudo da Teologia, os teólogos passam a debruçar-se sobre o direito das gentes. A Espanha, em especial, conhece uma renovação tão profunda de interesse pela Escolástica que esse período se torna conhecido como neo-Escolástica, ou Segunda Escolástica. Como ele coincide com as Grandes Navegações, a Espanha experimenta o seu "século de ouro".

A Europa sofria profundas mudanças. Além da descoberta do Novo Mundo, data desta época a invenção da pólvora e da artilharia, a redescoberta da Antigüidade Clássica, a invenção da imprensa - que disseminou a palavra escrita - e do compasso marítimo, o desenvolvimento da idéia de soberania e o surgimento dos primeiros Estados nacionais. Com

\footnotetext{
${ }^{30} \mathrm{Cf}$. HAGGENMACHER, Peter. Grotius et la doctrine de la guerre juste. pp. 331-333.
} 
tantos progressos tecnológicos - os quais, de fato, alteraram a concepção de mundo -, a Teologia passou a se ocupar também de questões humanas.

Um dos maiores autores desse tempo apresenta-se Francisco de Vitória. Por mais ortodoxo e fiel ao tomismo que fosse, ele vivia num mundo diferente daquele de Santo Tomás, e precisou confrontar-se com problemas inéditos; entre outros, a capacidade dos índios e o desfazimento da noção de império universal cristão. As Grandes Navegações haviam diminuído o tamanho do planeta e revelado uma multiplicidade de povos pagãos. Pela primeira vez, parecia possível um rei se tornar senhor de todo o mundo. E, também pela primeira vez, o cristianismo não parecia tão universal assim. Vitória tratou, pois, de atualizar Santo Tomás.

O problema da alma dos índios trazia consigo uma delicada conseqüência jurídica: se povos não-cristãos poderiam exercer, de maneira válida, domínio sobre seus territórios. Segundo uma concepção muito divulgada, da noção extraída do Antigo Testamento de "terra prometida", diversos canonistas concluíram que, tal como Deus havia presenteado a Palestina para um determinado povo (os judeus), Deus havia doado o mundo inteiro para os cristãos quando da vinda de Cristo. Assim, o credo "correto", o cristianismo, consistiria num requisito para a aquisição válida de um território, e os infiéis poderiam ser legitimamente privados de suas terras. $^{31}$

Cumpre salientar que os cristãos não se mostravam de todo intolerantes. Na metade do século XIII, o Papa Inocêncio IV reconhece que os infiéis podem ser titulares de domínio, posse e jurisdição. ${ }^{32}$ Todavia, os infiéis deste tempo resumiam-se aos muçulmanos, uma civilização tão ou mesmo mais avançada do que a européia. Como os cristãos, os islâmicos adoravam um Deus único, também professavam uma "religião do livro" e, junto com os judeus, observavam princípios morais que um europeu poderia reconhecer. No relacionamento entre os povos de religião monoteísta, ainda que não vigorasse a paz, existia respeito. Mas o que dizer de crenças que cultuam diversos deuses, inclusive personificações de forças naturais, praticam canibalismo e sacrifícios humanos? A distância em relação às religiões reveladas apresenta-se grande demais. Não há diálogo possível.

Uma vez que o destinatário da tolerância do Pontífice Inocêncio IV era outro, o Islã, não deve causar surpresa a Igreja não aplicar essa posição em relação aos índios. Em 14 de

\footnotetext{
${ }^{31}$ Cf. STUMPF, Christoph A. Christian and Islamic Traditions of Public International Law. Journal of the History of International Law, n. 7, 2005, pp. 71-72.

${ }^{32}$ Cf. TIERNEY, Brian. Vitoria and Suarez on Ius Gentium, Natural Law and Custom. In: The Nature of Customary Law: Philosophical, Historical and Legal Perspectives. Centre for Research in the Arts, Social Sciences and Humanities: University of Cambridge, 2004. p. 8.
} 
maio de 1493, na famosa bula Inter caetera, o Papa Alexandre VI doou aos reis católicos as "ilhas remotíssimas e as terras firmes" já descobertas por Colombo e "as que se descubram depois", para que possam exercer "plena autoridade e jurisdição" a ocidente de um meridiano ideal conhecido como "linha Alexandrina", que passava a cem léguas a oeste das ilhas de Açores e Cabo Verde. Em 7 de junho de 1494, o Tratado de Tordesilhas, imbuído desse mesmo espírito de divisão do mundo, modificaria os limites preestabelecidos. ${ }^{33}$

No entanto, mesmo no século XVI, discutia-se a hipótese da bula papal conter autoridade o suficiente para transferir o domínio pleno dessas terras - descobertas e ainda por descobrir (frise-se) - ou haver tão-somente repartido a autoridade competente entre dois príncipes para a predicação cristã. Este último caso configuraria o que, em linguagem moderna, se denomina de "esferas de influência"; o exercício do poder, porém, condicionarse-ia à propagação da fé.

Francisco de Vitória iria defender esta última tese. Contudo, ele precisaria sobrepujar interesses quase invencíveis. A teoria rival da doação aparece no Requerimento redigido pela Junta de Burgos de 1512, obra de López Palacios Rubios. Após remontar à Criação do universo, o documento afirma que Deus confiou a São Pedro todos os homens, onde quer que vivam e sobre qualquer lei, seita ou crença que observem, para lhes servir de cabeça e senhor, e concedeu o mundo inteiro por seu reino e jurisdição. A seguir, refere-se, de forma expressa, ao ato de Alexandre VI como "doação". Nessas linhas, aparecem todos os principais elementos de uma concepção variante do monismo imperial medieval que estabelece o Sumo Pontífice, em vez do imperador, como o senhor de todo o mundo. Esta teoria havia sido advogada por diversos canonistas, como o Cardeal Hostiensis e Inocêncio III, na decretal Novit Ille, e também por alguns teólogos, em especial, os espanhóis Álvaro Pelayo e Rodrigo Sánchez Arévalo. ${ }^{34}$ A defesa da tese oposta não iria só contrariar a política oficial da Espanha, mas poria o seu expositor em rota de colisão com o próprio papa.

Vitória ocupava o cargo de prima professor de Teologia em Salamanca, e suas opiniões mereciam respeito. Entretanto, para o dissabor de muitos, ele não endossava o monismo pontifício, nem a guerra contra os índios. Para Vitória, Deus havia distribuído a sua autoridade para todos os povos, não só os cristãos. Os índios também poderiam possuir terras e exercer soberania, pois se encontravam em “domínio pacífico de suas coisas públicas e

\footnotetext{
33 Cf. BARTHÉLEMY, Joseph. François de Vitoria. In: PILLET, Antoine. Les Fondateurs du Droit International. Paris: V. Giard \& E. Brière, 1904. p. 15.

${ }^{34}$ Cf. VIEJO-XIMÉNEZ, José Miguel. "Totus orbis, qui aliquo modo est una republica”. Francisco de Vitoria, el Derecho de Gentes y la expansión atlántica castellana. Revista de Estudios Histórico-Jurídicos, n. 26, Sección Historia del Pensamiento Jurídico, Valparaíso, 2004, p. 365.
} 
privadas. Logo (salvo outro óbice em contrário), devem ser considerados verdadeiros senhores e, nessas circunstâncias, não se pode despojá-los de suas posses"35.

Dessa feita, as Relecciones, quando publicadas, só escaparam do Index de obras proibidas por causa da inesperada morte do Papa Sexto V. Mas o rei sequer esperou a publicação. Em 1539, o Prior do Convento de Santo Estevão, Domingo de Soto, vespera professor de Teologia e seguidor de Vitória, recebeu uma carta assinada pelo próprio Carlos V que proibia os clérigos desse monastério de expressar posições que fossem de encontro à política ultramarina de Castela. Qualquer manifestação em contrário seria considerada uma ofensa pessoal. ${ }^{36}$ Tratava-se de uma indisposição bastante pontual e limitada a esta questão, porque, em diversos episódios anteriores e mesmo posteriores, o rei manifestou o seu apreço e admiração por Vitória.

Por esse motivo - por causa da coragem de Vitória na defesa de suas idéias -, e em razão do afã pela busca de um novo pai para o direito internacional, lapidou-se uma imagem imaculada e um tanto caricata do dominicano. Cometeram-se dois exageros: Vitória, tal como seu irmão de ordem Las Casas, tornou-se um campeão na defesa dos direitos dos índios e o primeiro a apresentar uma visão moderna de direito internacional. Em outras palavras, o teólogo de Salamanca, segundo esta literatura, desenvolveu um conceito de jus gentium até então inédito, que regulamenta tanto os períodos de guerra como os de paz, e que incide sobre Estados soberanos; essa soberania, porém, não se mostra absoluta, porque haveria um princípio superior que a limita: o totus orbis, uma comunidade internacional e orgânica de todos os povos, que estabelece elos de solidariedade com vistas a um bem comum. Essa instância mundial encontra-se acima das vontades particulares dos Estados, edita normas internacionais e assegura a sua execução. Os próprios Estados, em virtude de um “desdobramento funcional”, funcionam como órgãos do orbis e valem-se da guerra justa para vindicar injustiças e corrigir enganos. ${ }^{37}$

Essa concepção, segundo a qual Vitória já teria desenvolvido uma definição moderna de direito internacional, se funda no seguinte raciocínio. Como um legítimo herdeiro de Tomás de Aquino, Vitória compartilha da idéia da solidariedade natural do homem e da

\footnotetext{
35 “(...) in pacifica possessione rerum et publice et privatim. Ergo omnino (nisi contrarium constet) habendi sunt pro dominis. Neque in dicta causa possessione deturbandi" (VITORIA, Francisco de. Obras de Francisco de Vitória. Relecciones Teologicas. Editadas por Teofilo Urdanoz. Madrid: Biblioteca de Autores Cristianos, 1960. De Indis, Relectio 1, 5. p. 651).

${ }^{36}$ Cf. SCOTT, J. B. The Spanish Origin of International Law. Francisco de Vitoria and his law of nations. 2. ed. New Jersey: The Law Book Exchange, 2003. pp. 84-85. Neste livro, o autor reproduz a carta.

${ }^{37}$ Esta corresponde à concepção institucionalista de DELOS, J. T. La Société Internationale et les Principes de Droit Public. 2. ed. Paris: Pédone, 1950. pp. 187-228. Para a tese tradicional mais "pura", confira todo o livro SCOTT.
} 
conseqüente naturalidade do Estado. E a sociedade internacional forma uma comunidade assemelhada a um Estado: "E o mundo todo, que de certo modo forma uma república, tem o poder de prescrever, a todos os súditos, leis justas, como são as de direito das gentes." ${ }^{\text {,3 }}$

Da mesma maneira que as repúblicas consistem em agrupamentos naturais formados por indivíduos, existe outra comunidade natural que se compõe de repúblicas, e sobre elas exerce autoridade. Trata-se, segundo essa interpretação, de uma analogia com o próprio Estado; este seria o significado da oração aliquo modo est una republica. O orbe representa um corpus natural e orgânico, cujos membros são todas as repúblicas. Como qualquer comunidade política, ele promulga verdadeiras leis: "o direito das gentes não tem força somente pelo pacto e convênio dos homens, mas tem verdadeira força de lei”39. Assim, o jus gentium independe da vontade dos Estados. O totus orbis constitui uma instância legislativa superior à mera soma de todos os seus membros.

Portanto, a soberania dos Estados resta limitada por um poder superior: o bem comum, o motivo pelo qual se constituiu o orbe. A solidariedade natural dos indivíduos torna-se um princípio válido para as relações internacionais. Um evento político que interessa um Estado afeta a todos. Assim, a justiça desse acontecimento deve ser mensurada de maneira global. “Como cada república é uma parte de todo o mundo, e sobretudo uma província cristã parte de uma república, se a guerra fosse útil a uma província ou a uma república, mas fosse prejudicial ao mundo ou à cristandade, penso que por esse fato ela seria injusta." ${ } 40$

Contudo, o principal argumento ainda estaria por vir. A literatura que buscou estabelecer Francisco de Vitória como o novo pai do direito internacional encontrou fundamento para a sua pretensão na famosa passagem em que o teólogo de Salamanca retoma a definição de jus gentium de Gaio: "Mas o que a razão natural estabeleceu entre todas as gentes se chama direito das gentes" ${ }^{\prime 1}$ (grifo nosso). Vale a pena repetir o supracitado trecho final da definição do jurisconsulto romano: "Mas o direito que a razão natural estabeleceu entre todos os homens é uma regra segundo a qual todos observam igualmente e se chama direito das gentes, na medida em que é o direito que todas as nações se servem" (grifo nosso). Vitória substitui no texto original a palavra homines por gentes. Consoante essa literatura, não

\footnotetext{
38 "Habet enim totus orbis, qui aliquo modo est una republica, potestatem ferendi leges aequas et convenientes omnibus, quale sunt in iure gentium." (VITÓRIA, Francisco. Op. Cit., De potestate civili, 21. p. 191).

39 "Quod ius gentium non solum habet vim ex pacto et condicto inter homines, sed etiam habet vim legis" (VITÓRIA, Francisco. Op. Cit., De potestate civili, 21. p. 191).

40 "Imo cum una respublica sit pars totius orbis et maxime christiana provincia pars totius reipublicae, si bellum utile sit uni provinciae, aut reipublicae, cum damno orbis aut christianitatis, puto eo ipso bellum esse iniustum." (VITORIA, Francisco de. Op. Cit. De potestate civili, 13. p. 168).

41 “Quod naturalis ratio inter omnes gentes constituit, vocatur ius gentium" (VITORIA, Francisco de. Op. Cit. De indis I, III, 2. p. 706).
} 
se trata de um pequeno engano por causa de uma citação das Institutas feita de memória pelo autor. A troca teria sido proposital e traria conseqüências bastante profundas: o sujeito do direito das gentes não mais seriam os homens - o que, conforme visto, confundia este ramo com o direito natural -, mas os povos.

\begin{abstract}
Esta inovação tem uma importância fundamental. Pois, com a substituição de gentes em lugar de homines, o antigo direito romano, que servia para reger as relações entre todos os homens por todas as partes do mundo, queda convertido num direito que rege as relações dos vários povos considerados como nações, ou melhor, como Estados. ${ }^{42}$
\end{abstract}

Assim, Vitória deixaria, em definitivo, a órbita romana e seria o primeiro a apresentar um conceito de jus gentium que corresponde ao de direito internacional contemporâneo. Ainda, para corroborar esta interpretação, a frase seguinte à passagem se inicia com Apud omnes enim nationes, o que permitiu de vez identificar as gentes de Francisco de Vitória com “nação", e não mais com "homens", como era no texto de Gaio.

No entanto, essa literatura produziu uma versão um tanto direcionada da obra de Vitória. Os autores dessa época procuravam um substituto para Hugo Grócio, então trataram de fazer o maestro espanhol falar mais do que havia sido a sua intenção. Uma leitura a partir das próprias premissas de Vitória, em vez dessa permeada por pré-concepções atuais, revela um pensador preocupado em promover "os valores especificamente cristãos e em justificar aquilo que os espanhóis chamam com franqueza de conquista"43.

A estrutura mesma das Relecciones sobre os Índios mostra o propósito de Vitória. $\mathrm{Na}$ primeira relección, a primeira seção inteira busca demonstrar que os índios possuem suas terras de maneira válida. Essa demonstração, inobstante as profundas conseqüências jurídicas, serve a um propósito maior: comprovar que o infiel pode ter domínio. Professar outra religião que não a verdadeira não constitui motivo para despojar os hereges de seus bens. Posse, propriedade, domínio e soberania representam institutos independentes de religião. Com isso, o autor prepara-se para atacar a idéia de que o papa poderia exercer jurisdição sobre o mundo inteiro.

\footnotetext{
42 "Esta innovación tiene una importancia fundamental. Pues, con la substituición de gentes en lugar de homines, el antiguo derecho romano que servía para regir las relaciones entre todos los hombres por todas las partes del mundo, queda convertido en un derecho que rige las relaciones de los varios pueblos considerados como naciones, o bien, como estados." (SCOTT, J. B. Conferencias del Presidente del Instituto Americano de Derecho Internacional preparadas en homenaje a la Universidad Mayor de San Marcos, Lima, Universidad Mayor de San Marcos, 1938. p. 20).

43 “(...) des valeurs spécifiquement chrétiennes et à justifier ce que les Espagnols appelaient sans ambages une conquête" (HAGGENMACHER, Peter. 1492 Le choc de deux mondes. Actes du Colloque. COMISSION NATIONALE SUISSE POUR L'UNESCO. Genève: La Différence, 1993. p. 215).
} 
Essa lição cumpre o papel de introduzir a segunda seção. Nesta, Vitória procura refutar os títulos não-legítimos pelos quais os espanhóis conquistaram os "bárbaros do Novo Mundo" (barbari novi orbis). São os títulos previstos no Requerimento de Burgos. O primeiro afirma que o imperador é senhor do mundo. Vitória não poderia aceitar isso porque, de fato, não vivia mais num ambiente feudal. O imperador romano-germânico já ostentava um poder mais simbólico do que efetivo. Assim, Carlos V não poderia reivindicar as terras indígenas por sua própria autoridade. No segundo título, o autor rechaça o monismo pontifício. O papa não exerce jurisdição temporal em todo o orbe, porque Deus nunca fez essa doação. O terceiro título corresponde ao descobrimento. Todavia, aquelas terras não eram desprovidas de donos, por isso não há que se falar em nova aquisição. O quarto título refere-se à recusa dos índios em receber a fé de Cristo. Vitória não aceita este porque ele nega a legitimidade de todas as conversões forçadas. Pelo quinto título, os espanhóis poderiam declarar guerra aos índios por causa dos pecados destes; os quais atentariam não só contra a lei positiva divina, mas também contra a lei natural. Os índios comeriam carne humana e praticariam o incesto. Este motivo é bastante grave, mas o papa não exerce jurisdição espiritual sobre os não-convertidos e, pois, não poderia delegar a autoridade para corrigi-los. O sexto título corresponde à submissão voluntária dos índios aos espanhóis. Além do fato de que o medo e a ignorância viciam este tipo de eleição, os hereges já têm soberano. Por fim, o último título conferiria aos espanhóis direitos sobre todos os bárbaros por uma doação especial de Deus. Vitória não se detém muito aqui porque este argumento não se comprova nem pelas Escrituras, nem por milagre.

Até o momento, os escritos parecem fazer jus à imagem de Vitória como um santo humanista; entretanto, a relección prossegue. Na terceira seção, o autor passa a analisar os títulos legítimos pelos quais os espanhóis podem conquistar os bárbaros. O primeiro diz respeito à comunicação natural que subsiste em todo o mundo. Os espanhóis possuem o direito de visitar e de se estabelecer nas terras dos índios, sem sofrer dano algum. Se este acontecer, será lícito guerrear. Deste título, deriva-se ainda a legitimidade do comércio, do uso das coisas comuns e da migração. Todos estes institutos pertenceriam ao direito das gentes, e um descumprimento constitui motivo de guerra justa. O segundo título refere-se à propagação da religião cristã. Os índios não são obrigados a se converterem, mas devem suportar a evangelização. Este dever não é de direito das gentes, mas oriundo da verdadeira fé, e parece improvável que Vitória admitisse a reciprocidade. O terceiro e quarto título também correspondem a matéria de fé. Se alguns bárbaros se converterem, seus príncipes não podem empregar a força para volvê-los à idolatria, sob pena de uma guerra justa. E, após essa conversão ao cristianismo, o papa pode, com justa causa, conceder um príncipe cristão aos 
índios. O quinto título corresponde à tirania dos senhores bárbaros que promulgam leis inumanas com o sacrifício de inocentes. Trata-se do que se pode qualificar como o embrião de uma intervenção humanitária. No sexto, Vitória retoma a idéia de submissão voluntária ao rei da Espanha, mas ressalta que o consentimento deve ser válido. O sétimo título refere-se a alianças que algumas tribos podem fazer com os espanhóis contra outras. Neste caso, é permitido prestar auxílio aos aliados. Por fim, se houver mesmo alguma comunidade incapaz de se governar, então, por caridade, os espanhóis podem conduzi-la. Contudo, devem fazê-lo não em proveito próprio, mas dos bárbaros.

Ainda, cabe acrescentar que toda a Segunda relectio sobre os índios versa sobre o próprio direito da guerra dos espanhóis sobre os bárbaros.

Assim, o dominicano faz regressar em novas bases tudo o que ele já havia refutado. $\mathrm{O}$ fato de os índios possuírem domínio não exclui a possibilidade de interdição. O papa pode não exercer jurisdição sobre eles, mas conta com um poder indireto. Os espanhóis podem lá se estabelecer, em virtude de uma sociedade natural de comunicação. Proíbe-se a conversão forçada, mas os índios devem suportar a evangelização. Práticas bárbaras, como sodomia e canibalismo, não justificam uma intervenção, mas esta pode ocorrer em defesa dos inocentes. Todas essas posições não se ajustam muito bem com a imagem de um defensor dos direitos dos indígenas.

Vitória era, com absoluta certeza, um homem de convicções. Não aceitava as teses oficiais do Requerimento para a conquista dos índios, nem a idéia de que o papa poderia exercer autoridade sobre todo o mundo, mesmo o não-cristão. Mas era também tanto um patriota, como um defensor da fé cristã, ainda que a sua doutrina o afastasse dos argumentos corriqueiros de seu tempo. No debate entre Bartolomeu de Las Casas e Juan Ginés de Sepúlveda sobre o direito dos índios, Francisco de Vitória situava-se no meio.

Mas o que dizer daquelas afirmações expressas de Vitória que expressariam a idéia de uma sociedade internacional, que limita a soberania dos Estados e que se rege pelo direito? De fato, o teólogo de Salamanca menciona com frequiência a expressão totus orbis ou mesmo a variante totus mundus. Não há dúvidas de que ela constitui um quadro referencial, mas causa estranheza o fato de o autor nunca a definir. Haggenmacher analisa, nas obras de Vitória, todas as passagens em que os termos aparecem. Nalgumas vezes, eles possuem um sentido meramente factual e designam o "mundo inteiro", como uma realidade geográfica. Noutras mais raras, eles denotam uma entidade moral, investida de auctoritas ou potestas. Nestas, o totus orbis aparece como fonte ou do direito das gentes, ou somente do direito da 
guerra exercido a título de sanção pelos soberanos. ${ }^{44}$ Portanto, cumpre verificar se nestas ocasiões Vitória deseja introduzir uma noção original, assemelhada àquela de sociedade internacional.

Em comentário ao Tratado da Justiça de Santo Tomás, Vitória analisa a questão 57 que, como visto, considera o jus gentium um direito positivo. A obscuridade do pensamento do Aquinate sobre a natureza do direito das gentes terá reflexos na obra de Vitória: em determinados momentos, o jus gentium pertence ao direito natural, noutros, ao direito positivo. Neste texto, o dominicano opta por este último. Trata-se, contudo, de um direito positivo bastante singular em virtude da aparente ausência de legislador. Isso ocorre porque o direito positivo se manifesta de duas maneiras: pela condicta privata - que procede dos contratos ordinários entre particulares - e pela condicta publica - que se origina das convenções adotadas pelo conjunto de uma comunidade. ${ }^{45}$ Estas, normalmente, aparecem sob a forma de leis, o que garante a sua publicidade. Porém, quando se refere a um acordo entre todos os povos e nações do mundo inteiro, a publicidade é um elemento implícito. Segundo Haggenmacher, Vitória pretendia transpor uma distinção de direito civil para o direito das gentes. O aspecto público advém da universalidade da convenção. A linguagem do autor, portanto, mantém-se na esfera contratual, e o orbis não designa uma entidade autônoma e superior. A expressão corresponde tão-somente a um modo cômodo de se reportar à soma dos Estados. ${ }^{46}$ Portanto, neste texto, apesar de aparentar uma fonte legislativa, o totus orbis não representa uma pessoa moral.

Entretanto, como explicar a passagem na Relectio de potestate civili, a já mencionada aliquo modo est una republica, na qual o totus orbis promulga verdadeiras leis? O trecho, em verdade, apresenta-se como um corolário da demonstração que o precede. Vitória questiona se as leis civis obrigam também os legisladores e os reis (“An leges civiles obligent legislatores et maxime reges?"). Esta pergunta justifica-se porque alguns acreditam que eles se encontram acima de toda a república e, por conseguinte, não haveria nenhum poder superior para constrangê-los. Segundo o teólogo de Salamanca, os soberanos também integram a república, e, como a lei é válida para toda a comunidade, eles também devem observá-la. Em relação aos soberanos, ocorre o que se passa com os contratos: antes de acordar, a pessoa é livre, mas,

\footnotetext{
${ }^{44}$ Cf. HAGGENMACHER, Peter. La place de Francisco de Vitoria parmi les fondateurs du droit international. p. 39.

${ }^{45}$ Cf. VITÓRIA, Francisco de. De Jure Gentium et Naturali. In: SCOTT, J. B. The Spanish Origin of International Law, Appendiz E, p. cxii.

${ }^{46}$ Cf. HAGGENMACHER, Peter. La place de Francisco de Vitoria parmi les fondateurs du droit international. p. 41.
} 
depois da convenção, ela se obriga. A seguir, Vitória infere o corolário: “o direito das gentes não tem força apenas por causa do pacto e convenção dos homens, mas possui verdadeira força de lei. E o mundo todo, que de certo modo forma uma república, tem o poder de prescrever, a todos os súditos, leis justas, como são as de direito das gentes." ${ }^{\text {,4 }}$

Com essa afirmação, o autor deseja acentuar o caráter legal do direito das gentes. Contudo, isso não conflita com a natureza contratual acima exposta, pois a condicta publica possibilita essa equiparação com a lei. A ênfase deve-se a um raciocínio desenvolvido anteriormente. Vitória defende que a lei positiva, de modo diverso da lei natural, incide sobre ações que eram antes moralmente neutras. Mas, depois de editada uma lei positiva, a ação se torna proibida ou obrigada também pela lei natural. "Do que se depreende que pecam mortalmente todos os que violam os direitos das gentes" ${ }^{\text {"48 }}$. O dominicano não procurou contrariar uma constatação anterior e alterar a origem convencional do jus gentium, mas ressaltar o argumento de que este direito também obriga em consciência.

Na Preleção sobre os índios, Vitória apresenta um duplo fundamento de validade ao direito das gentes: em algumas vezes, o direito natural, noutras, o consentimento humano. "Mas o que a razão natural estabeleceu entre todas as gentes se chama direito das gentes". Ou: "E uma vez que nem sempre se derive [o direito das gentes] do direito natural, parece que basta o consentimento da maior parte do mundo, sobretudo se é para o bem comum de todos." 49 (grifo nosso). É revelador o fato de Vitória ter pronunciado esta lição um decênio após a anterior. Se o dominicano decidiu debruçar-se sobre a natureza do jus gentium, mudou de opinião com os anos; de positivo, o direito das gentes passou a pertencer parte ao direito natural e parte ao direito positivo. Ou, ainda, resta a alternativa de que ele nunca haveria se preocupado com o jus gentium, e esse duplo fundamento denota a sua indiferença à questão. Em ambas as possibilidades, Vitória afasta-se de uma concepção mais moderna de direito internacional.

Perceba-se que, neste último excerto, o jus gentium não retira a sua validade do totus orbis, mas da maioris partis totius orbis. A alteração - sem dúvida - resulta do alargamento do campo de visão que a descoberta dos "bárbaros do Novo Mundo" proporcionou. Isso

\footnotetext{
47 "Quod ius gentium non solum habet vim ex pacto et condicto inter homines, sed etiam habet vim legis. Habet enim totus orbis, qui aliquo modo est una republica, potestatem ferendi leges aequas et convenientes omnibus, quale sunt in iure gentium." (VITÓRIA, Francisco. Op. Cit., De potestate civili, 21. p. 191).

48 "Ex quo patet quod mortaliter peccant violantes iura gentium" (VITÓRIA, Francisco. Op. Cit., De potestate civili, 21. p. 191).

49 "Quod naturalis ratio inter omnes gentes constituit, vocatur ius gentium" e "Et dato quod non semper derivetur ex iure naturali, satis videtur esse consensus maioris partis totius orbis, maxime pro bono communi omnium." (VITORIA, Francisco de. Op. Cit. De indis I, 3, 2. p. 706 e I, III, 4. p. 710).
} 
produz conseqüências bastante interessantes. O consentimento da maioria da humanidade pode impor-se sobre o mundo inteiro, mesmo contra a vontade de uma minoria (que não é tão esclarecida).

É nessa imposição que se baseia a legitimidade da guerra que os europeus podem travar contra os índios, abordada na segunda preleção sobre os índios. Os príncipes exercem autoridade não só sobre seus súditos, mas também sobre estrangeiros para impedi-los de cometer erros. E esse poder decorre da autoridade de todo o orbe ${ }^{50}$ Além da defesa do colonialismo espanhol, para o presente propósito, deve extrair-se outra consequiência. Nas duas lições sobre os índios, o orbe parece mesmo constituir uma fonte legislativa, por vezes de todo o jus gentium, por vezes apenas do poder vindicativo dos soberanos.

No entanto, salienta Haggenmacher que, em nenhum momento, Vitória investiga a figura do orbe em si. Ela aparece sempre em relação a outros problemas (o direito das gentes e o poder vindicativo) e nunca como o centro da discussão. Por esta razão, o seu conceito resta indeterminado. Por conseguinte, nas raras ocasiões em que o totus orbis se apresenta como um todo orgânico, superior à soma dos Estados, o autor não poderia estar referindo-se a uma realidade nova, a qual deveria demandar uma análise mais detida. Trata-se, portanto, de algo bastante velho, que dispensa apresentações e, por isso, provavelmente se perde num passado imemorial: o orbis christianus. ${ }^{51}$ A Respublica Christiana correspondia a um quadro de referências antigo, que todo europeu conhecia. O totus orbis consiste numa abstração marginal dessa concepção, que já havia deixado de ser uma experiência. Significa uma atualização de uma realidade pretérita (ainda não esquecida de todo) por causa da descoberta de povos não-cristãos no Novo Mundo, mas que, de uma forma ou de outra, terminaram por se encontrar sob a jurisdição de povos cristãos.

A distinção entre cristãos e não-cristãos revela-se essencial para a compreensão do direito das gentes de Vitória. Assim como o jus gentium romano regia as relações entre romanos e estrangeiros, o jus gentium do teólogo de Salamanca governa as relações entre cristãos e não-cristãos. E, tal como aquele não guardava semelhança com o direito internacional contemporâneo, porque se aplicava no interior do Império Romano, este incide dentro de um império europeu alargado pelas Grandes Descobertas. Trata-se do direito interno de uma comunidade multi-religiosa mas de jurisdição cristã.

\footnotetext{
${ }^{50}$ Cf. VITÓRIA, Francisco de. De Jure Belli. 20 In: SCOTT, J. B. The Spanish Origin of International Law, Appendiz B, p. lvi. Cabe observar que aqui esta norma de direito das gentes se funda no direito natural.

${ }^{51}$ Cf. HAGGENMACHER, Peter. La place de Francisco de Vitoria parmi les fondateurs du droit international. pp. $45-46$.
} 
As teses e ilustrações de Vitória foram pensadas em função do orbis christianus. O que ele fez foi derivar as conseqüências para toda a humanidade. Assim, da mesma maneira que cada província cristã integra a cristandade européia, cada república faz parte do orbe. E o exemplo que o autor utiliza, na lição sobre a potestade civil, para comprovar que cada Estado possui uma ligação orgânica com o mundo inteiro se mostra bastante sugestivo. Afirma Vitória que um Estado, mesmo que possua uma causa justa, não deverá entrar em guerra se a mesma prejudicar o totus orbis. E “(...) se a guerra fosse dos espanhóis contra os franceses, mesmo que haja motivos justos e vantagem para a Espanha, caso a guerra cause maior dano e fratura para a cristandade, com o risco dos turcos ocuparem as províncias cristãs, deverá desistir-se dessa guerra" ${ }^{25}$. A ilustração do autor não se refere ao totus orbis, mas tão-somente à Respublica Christiana.

Consoante Haggenmacher, o teólogo de Salamanca escolheu um exemplo que iria, com toda a certeza, convencer seus expectadores, porque apelava para um receio geral que pairava sobre a atualidade política; porém, ele se ajusta mal ao conjunto do orbe, visto que era, como ainda é, uma perspectiva muito remota o mundo inteiro se tornar cristão. À época de Vitória, imaginar que o totus orbis poderia formar uma república só poderia ser aliquo modo. Trata-se de uma noção longínqua e impalpável, que foi evocada apenas para servir de explicação para certas regras de fundo; estas sim centrais ao raciocínio. Diversa é a situação no seio da cristandade, na qual Vitória poderia conceber sem qualquer dificuldade uma monarquia universal. ${ }^{53}$

E o que afirmar da modificação que o teólogo de Salamanca teria realizado na definição de jus gentium de Gaio (Quod naturalis ratio inter omnes gentes constituit, vocatur ius gentium)? Se esta alteração foi intencional, Vitória desejava mostrar que o sujeito do direito das gentes consiste nos Estados, não nos indivíduos. No entanto, mesmo sem analisar o conceito de Estado para Vitória, é possível demonstrar que esta questão nunca se apresentou ao autor.

Quando o dominicano indaga se os índios, antes da chegada dos espanhóis, possuíam a propriedade pública e privada de suas terras, ele não investiga a personalidade jurídica internacional dos índios, mas simplesmente a personalidade jurídica. Porque, em caso

\footnotetext{
52 “(...) ut si bellum hispaniarum esset adversus gallos alias ex causis iustis susceptum et alioqui regno hispaniarum utile, tamen cum maiore malo et iactura geritur christianitatis, puta qui turcae occupant interim provincias christianorum, cessandum esset a tali bello." (VITÓRIA, Francisco. Op. Cit., De potestate civili, 13. p. 168).

${ }^{53}$ Cf. HAGGENMACHER, Peter. La place de Francisco de Vitoria parmi les fondateurs du droit international. p. 46.
} 
afirmativo, os conquistadores não poderiam despojá-los de seus bens, e as teses do Requerimento de Burgos não se aplicariam. As atenções de Vitória não se voltam a uma suposta diferença entre propriedade pública e privada, mas à capacidade jurídica dos índios. Ele não busca comprovar o caráter estatal das comunidades dos bárbaros do Novo Mundo, e sim a natureza plenamente humana dos indivíduos que a compõem. E, adiante, quando o autor trata dos títulos válidos de intervenção, o foco constitui sempre a barbárie ou a infidelidade dos indivíduos. Vitória procura por almas para converter e salvar. ${ }^{54}$

O teólogo de Salamanca se ocupa de homens, não de Estados; até porque ele confunde o direito das gentes com o direito natural. A referência a Gaio encontra-se inserida no primeiro dos quatorze argumentos que visam demonstrar que os espanhóis podem visitar os índios. Na própria definição, o jus gentium decorre da razão natural. E o raciocínio inicia-se com "[p]rova-se, em primeiro lugar, pelo direito das gentes, que é direito natural ou dele derivado" $" 55$. Em oposição a sua tese anterior - segundo a qual o jus gentium procede de um acordo tácito -, Vitória aqui estabelece um fundamento natural. E não havia como isso ser diferente. Não existe nada em comum entre espanhóis e índios, salvo a própria natureza.

Dessa feita, na definição de Gaio, Vitória não deseja sublinhar o inter omnes gentes, mas a naturalis ratio. Então por que o autor substituiu homines por gentes? No trecho inteiro - reproduzido acima -, apesar de mencionar homines, o jurista de Justiniano também fala em populi e gentes, e é a presença deste que pode explicar a origem etimológica da expressão jus gentium. Vitória, pois, tentou invocar a fórmula de Gaio, que ele cita de forma aproximada. Para o dominicano, inter omnes gentes não difere de inter omnes homines. A continuação de um, apud omnes enim nationes habetur inhumanum, faz eco diretamente a do outro, apud omnes populos peraeque custoditur. Vitória, portanto, quis evocar a concepção romana de jus gentium, um direito interno comum com fundamento numa espécie de necessidade natural intrínseca.

Cumpre salientar que a escolha do termo nationes não se mostra de todo fortuita. Vitória parece lembrar-se da definição de direito natural de Santo Isidoro de Sevilha: "o

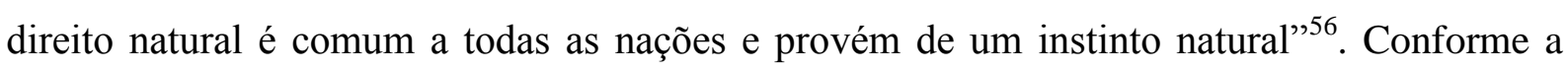
vocação de sua obra, Isidoro produz um jogo etimológico que pode passar despercebido por

\footnotetext{
${ }^{54}$ Cf. HAGGENMACHER, Peter. La place de Francisco de Vitoria parmi les fondateurs du droit international. pp. 50-56.

55 "Probatur primo ex iure gentium, quod vel est ius naturale, vel derivatur ex iure naturale" (VITORIA, Francisco de. Op. Cit. De indis I, III, 2. p. 706).

56 "Ius naturale commune omnium nationum, et quod ubique instinctu naturae" (ISIDORUS HISPALENSIS EPISCOPUS. Op. Cit., V, IV, 1).
} 
um leitor moderno. Já que o direito natural se aplica a todas as nações e se origina de um instinto natural, deve existir algo em comum a todas essas palavras: a raiz comum, o verbo nasci. O direito natural constitui, pois, um direito "de nascimento", que "nasce" junto com o homem, e não por uma convenção legislativa. Vitória, que por dever de ofício conhecia as Etimologias, quis discretamente insinuar essa conotação e inseriu a palavra nação para fazer correspondência ao ius naturale mencionado no início da passagem como fonte direta ou indireta do seu ius gentium. ${ }^{57}$

Não restam dúvidas de que aqui o autor concentra os seus esforços para conferir um fundamento ao direito das gentes. Mas este repousa na natureza, o que o distinguiria do direito internacional. E revela-se curioso que o primeiro Vitória - que embasa o seu jus gentium numa convenção - não parece tão preocupado com a fundamentação: "primeiro, a disputa diz respeito mais ao nome do que à coisa, porque importa pouco se alguém afirma isso [a pertença do direito das gentes ao direito positivo] ou aquilo [a pertença do ramo ao direito natural]"58. Quando Vitória se preocupa com o fundamento de validade, este decorre da natureza; quando ele considera a questão de somenos importância, a origem é de direito positivo.

Assim, o teólogo de Salamanca não consegue ultrapassar a concepção romana de jus gentium. Este ainda é um direito interno de um império, comum a diferentes povos (mas não entre esses povos) e que, por vezes, se confunde com o natural. Entretanto, de modo bastante paradoxal, a fraqueza dos argumentos de Vitória sobre o direito das gentes constitui a força de seu legado. Ainda que nunca houvesse concebido um direito entre sociedades políticas, o dominicano, de fato, substituiu homines por gentes. Embora nunca tivesse conferido um fundamento muito claro ao direito das gentes, em determinado momento, ele o considerou parte do direito positivo. Não obstante ter defendido o direito de intervenção dos espanhóis sobre os índios, ele concedeu aos "bárbaros do Novo Mundo" a possibilidade de domínio. E mesmo que o totus orbis não passasse de uma abstração inconseqüente, a expressão foi empregada de forma recorrente. Vitória estabeleceu as bases para que outra pessoa que o lesse pudesse discorrer sobre um direito entre os povos, de natureza positiva, inserto numa sociedade internacional que se sobrepõe à soberania estatal.

\footnotetext{
${ }^{57}$ Cf. HAGGENMACHER, Peter. La place de Francisco de Vitoria parmi les fondateurs du droit international. p. 61.

58 “(...) first of all the dispute concerns the name more than the thing, for it matters little whether one says this or that" (VITÓRIA, Francisco de. De Jure Gentium et Naturali. In: SCOTT, J. B. The Spanish Origin of International Law, Appendiz E, p. cxi).
} 


\section{Considerações Finais}

Até a publicação da obra de Antoine Pillet, Les fondateurs du droit international, a doutrina estava obstinada a encontrar um pai para o direito internacional. A lenda de um fundador único da disciplina coincidiu com a mitificação da figura de Hugo Grócio pela Escola do Direito da Natureza e das Gentes, e, durante trezentos anos, este autor desfrutou desse título. No entanto, quando se começou a questionar a modernidade do jurista holandês e a redescobrir a Escolástica Espanhola, constatou-se que o próprio Grócio possuía suas fontes, e a idéia de um direito entre os povos parecia mais velha.

Recorreu-se, pois, a uma tradição cristã - mas de valor universal - bastante antiga: a doutrina da guerra justa. A guerra corresponde à forma de intercurso mais extrema que os povos podem apresentar; desta feita, uma regulamentação da guerra significaria, de maneira clara, uma manifestação de um direito internacional. Ademais, todos os candidatos a pai da disciplina, Grócio e a Escolástica Espanhola, pertenciam a essa tradição, o que reforça a noção de que ela representa a origem desse direito. Deveria, então, procurar-se o primeiro autor a defender este corpo doutrinário.

Essa tarefa, contudo, não se mostra simples. As influências do direito de guerra medieval perdem-se na Antigüidade. Há reminiscências tanto hebraicas como helênicas e diversas afinidades com o jus fetiale romano. Parece, porém, existir um consenso na historiografia de que o primeiro escritor dessa tradição foi Santo Agostinho. Apesar desse acordo, as referências não-sistemáticas à questão da guerra, na obra do bispo de Hipona, não parecem traduzir uma preocupação com o tema da justiça numa guerra. Santo Agostinho, em verdade, ocupou-se da legitimidade de uma função pública: o serviço militar. Além dele, todos os autores da Alta Idade Média também não perceberam o direito da guerra como um problema autônomo.

Somente no século XII, essa doutrina passa a tomar forma. Embora ela ainda não fosse a preocupação central do monge Graziano, o Decreto Gratiano ocupa posição de destaque na história da guerra justa. Nele, há uma gama de referências e citações um tanto descontextualizadas da Patrística, mas que foram organizadas em função de questões pontuais, e a guerra constitui a Causa XXIII do decreto. A partir de então, os escritores seguintes poderiam investigar a guerra por ela mesma. Canonistas, teólogos e decretistas voltam suas atenções para a temática.

No século seguinte, um dos pensadores mais importantes de todos os tempos, Santo Tomás de Aquino, debruça-se sobre o problema da legitimidade da guerra. Para ser justa, ela 
precisa preencher três condições: autoridade competente, causa justa e intenção reta. Apesar de não aprofundar a análise sobre estes requisitos, em virtude da autoridade que sua obra adquire no Medievo, os mesmos se tornam referência obrigatória para os pensadores posteriores. O Aquinate, portanto, termina por conferir a formulação clássica à doutrina. Os seus seguidores apropriam-se dela de tal modo que se torna impossível dissociá-la da Escolástica, ainda que juristas leigos também tenham escrito sobre o direito de guerra.

Todavia, as influências da doutrina escolástica da guerra justa sobre o direito internacional revelam-se fugidias demais para poder aceitar-se a idéia de que esta disciplina se originou, em sua inteireza, dessa tradição. Boa parte dos autores da guerra justa sequer apresenta um conceito de jus gentium. Inferir que a justiça numa guerra implica, de modo necessário, a existência de um direito entre as gentes negligencia o papel desempenhado por um direito universal, racional e decorrente da natureza. $\mathrm{O}$ direito natural, desde os romanos, cumpre a função de fundamentar o direito comum entre povos e indivíduos, que não tenha emanado da vontade legislativa de uma civitas. Somente quando o conceito de direito das gentes adquirir autonomia face ao de direito natural, será possível afirmar que existe uma concepção moderna de direito internacional.

Ocorre que os romanos não eram bons filósofos e encontraram dificuldades para conferir um fundamento não-natural para o seu jus gentium. Cumpre salientar que, em Roma, este direito regia as relações entre estrangeiros dentro do Império. Não constituía um direito das gentes, mas das gens. Correspondia a um direito intra gentes, não inter gentes.

Os autores do Medievo herdam a tripartição direito natural, civil e das gentes, mas tampouco conseguem encontrar uma fundamentação distinta para este último. Em verdade, o jus gentium não consiste numa preocupação central na Idade Média; revela-se mais um legado incômodo, o qual não se sabe o que fazer com ele ou onde o colocar. Santo Isidoro de Sevilha, de fato, considera o jus gentium um direito positivo, mas a ausência de uma definição clara compromete a originalidade de seu intento. Parece provável que, influenciado pela concepção imperial cristã da época, o autor concebesse este ramo como um direito comum quase universal, mas que não regulamenta as relações entre os povos.

Em Santo Tomás de Aquino, o jus gentium traduz um dos modos de derivação da lei natural. Corresponde ao próprio direito natural aplicado a uma das facetas do convívio humano. A confusão com o direito positivo deve-se a uma definição deviante da palavra "positivo". Para o Aquinate, positivo significa humano. O jus gentium não é produzido pelo homem, como o direito civil. Mas ele exige um esforço "positivo" do intelecto do homem para derivá-lo dos princípios naturais. Trata-se de uma das inclinações que a lei natural 
produz em todos os homens, mas distinta das demais e exclusiva dos seres humanos. É um direito "humano" não por ser criado pelo homem, mas porque este não compartilha esse impulso (natural) com os demais seres.

A literatura que procurava uma paternidade única ao direito internacional voltou-se para o teólogo dominicano Francisco de Vitória. Nas lições deste, o jus gentium parecia aplicar-se aos mais distintos povos do mundo inteiro. Diante disso, essa literatura argüiu que, em Vitória, a soberania dos Estados se encontra limitada pela sua concepção de comunidade internacional: um todo orgânico, superior à soma das partes e fonte legislativa do direito das gentes. Ademais, concluiu que ele havia defendido os direitos dos índios contra os conquistadores espanhóis e proclamado a personalidade jurídica internacional daqueles. E, por fim, afirmou que o teólogo espanhol subverteu a definição de jus gentium de Gaio para adaptá-la ao conceito atual.

Contudo, essas conclusões, numa análise mais detida, revelam-se precipitadas. A estrutura mesma das suas lições sobre os índios denota um defensor da conquista espanhola, embora por motivos distintos daqueles oficiais. Nas raras ocasiões em que a expressão totus orbis designa uma entidade legiferante, o autor a concebe em função da unidade moral da cristandade européia. E a suposta subversão significa apenas uma citação de memória. Vitória não havia saído da órbita conceitual romana.

Ainda que não se possa denominar Francisco de Vitória o "pai" do direito internacional, não se pode menosprezar a sua importância, pois ele deixou elementos para outros completarem o seu trabalho. Mas, para que o jus gentium se tornasse direito internacional, faz-se necessário sepultar a idéia de monismo imperial ou de orbis christianus. O surgimento da "internacionalidade" encontra-se estreitamente vinculado ao ocaso do império universal.

\section{Referências}

AQUINO, Santo Tomas de. Suma Teologica. Texto latino de la edición crítica Leonina. Trad. Francisco Barbado Viejo, O.P. 2. ed. Madrid: Biblioteca de Autores Cristianos, 1947.

ARISTÓTELES. Ética a Nicômaco. Trad. Leonel Vallandro e Gerd Bornheim. São Paulo: Abril Cultural, 1973. (Coleção Os Pensadores).

BARCIA TRELLES, Camilo. Francisco Suárez: les théologiens espagnols du XVIe siècle et l'école moderne du Droit International. Recueil de Cours de l'Académie de Droit

International de Le Hague, 1933, n. 1, t. 43, Paris: Sirey. 
CÍCERO, Marco Túlio. Dos Deveres. Trad. Angélica Chiapeta. São Paulo: Martins Fontes, 1999; De Officiis. Paris: Garnier, s/d.

DELOS, J. T. La Société Internationale et les Principes de Droit Public. 2. ed. Paris: Pédone, 1950.

HAGGENMACHER, Peter. Grotius et la doctrine de la guerre juste. Genève, Paris: Heige, Presses Universitaires de France, 1983.

1492 Le choc de deux mondes. Actes du Colloque. COMISSION NATIONALE

SUISSE POUR L’UNESCO. Genève: La Différence, 1993.

ISIDORUS HISPALENSIS EPISCOPUS. Etymologiarum sive Originum Libri XX. ed. W. M. Lindsay. Oxford: Claredon Press, 1911.

IUSTINIANUS IMPERATOR. Corpus Iuris Civilis. ed. Krueger e Mommsen. Berlim: Weidmann, 1908.

LAGHMANI, Slim. Histoire du droit des gens: du jus gentium impérial au jus publicum europaeum. Paris: Pedone, 2003.

NUSSBAUM, Arthur. Historia del Derecho Internacional. Trad. Francisco Javier Osset. Madrid: Revista de Derecho Privado, 1953.

NYS, Ernest. Le Droit de la Guerre et les précurseurs de Grotius. Bruxelles, Leipzig: Murquardt, 1882.

PILLET, Antoine. Les Fondateurs du Droit International. Paris: V. Giard \& E. Brière, 1904.

RIVIER, Alphonse. Note sur la littérature du droit de gens avant la publication du Jus Belli ac Pacis de Grotius (1625). Bruxelles: Académie Royale de Belgique, 1883.

SCIACCA, Michele. Perspectiva de la metafisica en Sto. Tomas. Madrid: Speiro, 1976.

SCOTT, J. B. Conferencias del Presidente del Instituto Americano de Derecho Internacional preparadas en homenaje a la Universidad Mayor de San Marcos, Lima, Universidad Mayor de San Marcos, 1938.

The Spanish Origin of International Law. Francisco de Vitoria and his law of nations. 2. ed. New Jersey: The Law Book Exchange, 2003.

STUMPF, Christoph A. Christian and Islamic Traditions of Public International Law. Journal of the History of International Law, n. 7, pp. 68-80, 2005.

TIERNEY, Brian. Vitoria and Suarez on Ius Gentium, Natural Law and Custom. In: The Nature of Customary Law: Philosophical, Historical and Legal Perspectives. Centre for Research in the Arts, Social Sciences and Humanities: University of Cambridge, 2004. 
TRUYOL, Antonio. Noções Fundamentais de Direito Internacional Público. Trad. Ehrhardt Soares. Coimbra: Armênio Amado, 1952.

TRUYOL SERRA, Antonio et alii. Actualité de la Pensée Juridique de Francisco de Vitoria. Bruxelas: Bruylant, 1988.

VANDERPOL, Alfred. La Doctrine Scolastique du Droit de Guerre. Paris: A. Pedone, 1919.

VIEJO-XIMÉNEZ, José Miguel. “Totus orbis, qui aliquo modo est una republica”. Francisco de Vitoria, el Derecho de Gentes y la expansión atlántica castellana. Revista de Estudios Histórico-Jurídicos, n. 26, Sección Historia del Pensamiento Jurídico, Valparaíso, pp. 359391, 2004.

VIOLA, Francesco. Derecho de Gentes Antiguo e Contemporáneo. Trad. Isabel Trujillo. Persona y Derecho, n. 41, 2004.

VITORIA, Francisco de. Obras de Francisco de Vitória. Relecciones Teologicas. Editadas por Teofilo Urdanoz. Madrid: Biblioteca de Autores Cristianos, 1960.

WALKER, Thomas Alfred. A History of the Law of Nations. Cambridge: Cambridge University Press, 1899.

WIJFFELS, Alain. Early-Modern Literature on International Law and the Usus Modernus. Grotiana, v. 16-17, 1995-1996. 